\title{
Transactions of the Burgon Society
}

Volume 15

Article 5

$1-1-2015$

\section{The Iridescent Web: American Degree Colours (1895-1935)}

Kenneth L. Suit Jr

Milligan College

Follow this and additional works at: https://newprairiepress.org/burgonsociety

\section{Recommended Citation}

Suit, Kenneth L. Jr (2015) "The Iridescent Web: American Degree Colours (1895-1935)," Transactions of the Burgon Society. Vol. 15. https://doi.org/10.4148/2475-7799.1133

This Article is brought to you for free and open access by New Prairie Press. It has been accepted for inclusion in Transactions of the Burgon Society by an authorized administrator of New Prairie Press. For more information, please contact cads@k-state.edu. 
Transactions of the Burgon Society, 15 (2015), pages 41-74

\title{
The Iridescent Web: American Degree Colours (1895-1935)
}

\author{
By Kenneth L. Suit, Jr
}

Finding web of spider does not prove which spider spun web. -Charlie Chan's Secret (1936), 20th Century Fox

\section{Introduction}

The general history of American academic dress has been extensively chronicled in the 1 pages of this journal, ${ }^{1}$ but aside from noting that the faculty colours currently in use were added piecemeal during the hundred-odd years the 1895 Intercollegiate Code of Academic Costume and the 1935 Academic Costume Code have been in force, a detailed study of these colours has not been made. In large part this is because primary source material related to the selection and registration of American faculty colours has been considered ephemeral and often has not been kept in archival collections. For instance, in the 1980 purchase of the Cotrell \& Leonard company by the E. R. Moore company, followed by the acquisition of both by the Oak Hall company in 2005, no business records, correspondence, or catalogues from any of these academic regalia manufacturers were kept. ${ }^{2}$ The best source for information about faculty colours used in the United States, the Intercollegiate Bureau of Academic Costume, is difficult to contact, has not maintained its archive, and does not permit researchers to access whatever information still exists therein.

This means that many of the historical details about the evolution of American faculty colours cannot be known at this point, a complication that forces researchers like myself to write a more conjectural narrative of this history than we might desire. For instance, without archival correspondence from the Intercollegiate Bureau one cannot always know if the impetus for the adoption of a particular faculty colour came from an educational

I would like to thank Jeff Harbin, the former User Services Librarian of Milligan College, Tennessee, for his patient diligence in locating and obtaining via interlibrary loan the dozens of obscure catalogues and documents related to academic dress of the early 1900 s I coveted. I would also like to thank Susan Hoffman, Collection Manager, Arrangement and Description Archivist at the University of Minnesota archives, who was extremely helpful in photographing and sharing information about the fabric swatches from the archives of that institution.

1 See TBS, 9 (2009), for general information about the American system of academic dress, especially Stephen L. Wolgast, 'The Intercollegiate Code of Academic Costume: An Introduction', pp. 9-37; Robert Armagost, 'University Uniforms: The Standardization of Academic Dress in the United States', pp. 138-55; and David T. Boven, 'American Universities' Departure from the Academic Costume Code', pp. 156-74.

2 Telephone conversation with Donna Hodges, Vice-President, Oak Hall Cap \& Gown, 21 July 2014 
institution, professional association, or the Intercollegiate Bureau itself. So when primary source material is missing, I have suggested some possible origins of these faculty colours by noting the institutions-especially those in New York and other north-eastern statesthat first offered degrees in each of the particular disciplines represented in the official colour list of the Intercollegiate Bureau. For reasons explained later I consider these institutions to be the 'likely suspects' in causing the Bureau to select a particular faculty to assign a colour. Likewise, I will also suggest some possible symbolic or historical associations that might explain the Bureau's choice of colour for a particular discipline when the official rationale for the selection is unknown. I hope, however, that future scholars will be able to correct whatever narrative or historical errors have crept into this essay after additional archival material from the Intercollegiate Bureau is unearthed.

The 'Intercollegiate Bureau and Registry of Academic Costume' was an organization founded by Gardner Cotrell Leonard in $1887^{3}$

to record the correct colors of the institutions, the arrangement of the colors when more than one was employed, and any other particulars of the gowns, hoods, and caps used under the system or otherwise of all colleges and universities wherever located, and any other information as to their ceremonies.

Affiliated with the cap and gown department of the Cotrell \& Leonard firm in Albany, New York, the Bureau was the brainchild of Gardner Cotrell Leonard, who would become the director, promoter, and cheerleader for the Bureau's efforts to officially codify, register, and standardize the faculty colours used by colleges and universities in the United States. Leonard was a partner in his family's dry goods business, which sold hats, furs, and shoes before branching out in the early 1890s into the manufacturing of academic caps, gowns, and hoods.

Gardner Cotrell Leonard, the Cotrell \& Leonard firm, the Intercollegiate Bureau, and the 1895 Intercollegiate Code will be the recurring characters driving the narrative history of American faculty colours during the period covered in this essay, which ends the year the American Council of Education usurps the 1895 Code with its own 1935 Academic Costume Code. A future essay will trace the more complicated history of American faculty colours after that point, when the Intercollegiate Bureau, the American Council on Education, and a variety of academic regalia manufacturers maintained separate (and often conflicting) lists of faculty colours-a frustrating situation that continues today in careless affront to late-nineteenth-century efforts to standardize American academic dress.

\section{The Intercollegiate Code of Academic Costume (1895): The first degree colours}

In the 1890s, when American colleges and universities were beginning to emphasize their historic roots (or create them where they did not exist), they looked to the architecture, graphic designs, rituals, and academic garments still being used by their educational and cultural forefathers at Oxford and Cambridge. British faculty colours vary from university to university, but in the United States the Progressive Era zeitgeist for reform and insti-

3 Gardner C. Leonard, 'Academic Costume', in A Cyclopedia of Education, Vol. I, edited by Paul Monroe (New York: Macmillan, 1911), pp. 14-18, at 18. Vintage cardboard storage boxes for gowns and hoods from the Cotrell \& Leonard firm in the author's collection also state that the Bureau was founded in 1887. 
tutional standardization combined with a Gilded Age love of beauty inspired representatives from four east coast universities to form an 'Intercollegiate Commission' who drafted the 1895 'Intercollegiate Code of Academic Costume'. This Intercollegiate Code included a short list of eight American faculty colours that were to be displayed on the academic garments described in the Code and used by all the colleges and universities that voluntarily chose to abide by the stipulations of that Code.

Of the universities that participated in the Intercollegiate Commission, only two already used faculty colours on their academic costume, and both institutions were located in New York. Columbia University, the host of the Commission, was using a faculty colour scheme adopted only a year before the Intercollegiate Commission met: ${ }^{4}$

Faculty of Arts, Letters, and Philosophy: White

Faculty of Law: Pink

Faculty of Science: Gold Yellow

Faculty of Theology: Blue

Faculty of Medicine: Green

Since 1892 New York University had been using these faculty colours: ${ }^{5}$

Faculty of Arts and Philosophy: Violet

Faculty of Medicine: Crimson

Faculty of Law: Blue

Faculty of Divinity: Purple

Faculty of Science and Engineering: Yellow

Faculty of Pedagogy: White

The other two members of the Intercollegiate Commission-Princeton and Yale-did not use faculty colours on their academic regalia.

The Commissioners finalized the Intercollegiate Code of Academic Costume on 16 May 1895. The text of the Intercollegiate $\operatorname{Code}^{6}$ states that the colour of the trim on the academic hood (see Fig. 1) and, if black is not used, on the facings and sleeve bars of the doctoral gown (see Fig. 5) is:

distinctive of the Faculty to which the Degree pertains, thus:

Faculty of Arts and Letters, white.

Faculty of Theology, scarlet.

Faculty of Law, purple.

Faculty of Medicine, green.

Faculty of Philosophy, dark blue.

Faculty of Science, gold yellow.

Faculty of Fine Arts, brown.

Faculty of Music, pink.

The archaic wording of the Code sounds rather confusing, but to put it simply it was the title of the degree that determined the faculty colour, which is why in this article I will

4 This faculty colour system was adopted on 7 May 1894. See Columbia College in the City of New York: Revised Statutes (New York: Columbia College, July 1894), p. 36.

5 'New-York University', The New York Times, 24 April 1892.

6 See Appendix B. For what appears to be the original text of the Code, see 'Uniform Scheme of Academic Gowns and Hood', The Living Church Quarterly, 11.1 (1 Dec. 1895), pp. 59-64. Colleges and universities adopted the Code and often made minor changes to the text; these variant copies of the Code can be found in numerous college bulletins and catalogues of the period. 
be using 'degree colour' to describe the Intercollegiate system of faculty colour assignment. Gown and hood order forms from Cotrell \& Leonard, for instance, ask for the title of the degree, ${ }^{7}$ not the 'department or faculty of learning' as Leonard would write elsewhere, ${ }^{8}$ and in the 1930s the Intercollegiate Bureau would clearly state that: ${ }^{9}$

It is important to note that the reading of the degree, and not the department in which major work was done, governs the color proper for the velvet of the hood. Thus a degree conferred as 'Bachelor of Science in Engineering' requires the golden yellow of Science and not the orange of Engineering.

But why did the Commission select these eight degrees and why did they assign these eight colours to those degrees?

As for the degrees they selected-participating members of the Intercollegiate Commission of 1895 were from institutions that conferred the following degrees during that period:

Columbia University ${ }^{10}$

BA, BS, PhB, LLB, MA, LLM, EM, CE, EE, MetE, MD, PhD

New York University ${ }^{11}$

AB, BS, PhB, LLB, AM, MS, PhM, PdM, LLM, CE, PdD, MD, PhD

Princeton University ${ }^{12}$

BA, BS, AM, MS, CE, EE, DSc, PhD, LLD (hon), DD (hon)

Yale University ${ }^{13}$

BA, PhB, BCL, BD, BFA, MusB, LLB, MA, LLM, CE, ME, DCL, MD, PhD

So when this information is combined, one finds that the following degrees were granted by the participating institutions of the Intercollegiate Commission:

7 See, for just one of many examples, Concerning Caps, Gorens and Hoods, Bulletin 17 (Albany: Cotrell \& Leonard, n.d. but c.1902), p. 19.

8 Gardner Cotrell Leonard, The Cap and Gown in America (Albany: Cotrell \& Leonard, 1896), pp. 11-12. Written a year after the Intercollegiate Code was adopted, this publication is not the text of the Code but is Leonard's extrapolation or gloss of the Code, and he includes the list of degree colours in a different order from that in the Code. With minor variations Leonard's rearranged order of degree colours would be repeated in other publications by Cotrell \& Leonard for the next quarter century.

9 The History of Academic Costume in America (Albany: Cotrell \& Leonard for the Intercollegiate Bureau of Academic Costume, 1936), p. 11.

10 Columbia University Bulletin, 15 (Dec. 1896), (New York: Columbia University Press, 1896), pp. 76-77.

11 Compiled from lists of graduates in 1895 in the General Alumni Catalogue of New York University 1833-1905: College, Applied Science, and Honorary Alumni (New York: General Alumni Society, 1906); the General Alumni Catalogue of New York University 1833-1906: Law, Graduate, Pedagogy, Veterinary, Commerce, and Collegiate Division Alumni (New York: General Alumni Society, 1906); and the General Alumni Catalogue of New York University 1833-1907: Medical Alumni (New York: General Alumni Society, 1908).

12 Compiled from lists of graduates in 1895 in the General Catalogue of Princeton University 1746-1906 (Princeton: Princeton University Press, 1908).

13 Compiled from information in Yale Corporation: Miscellaneous Regulations (21 May 2013), Section 8, at <http://www.yale.edu/about/corporation/regulations.html\#eight>, accessed 25 March 2016. 


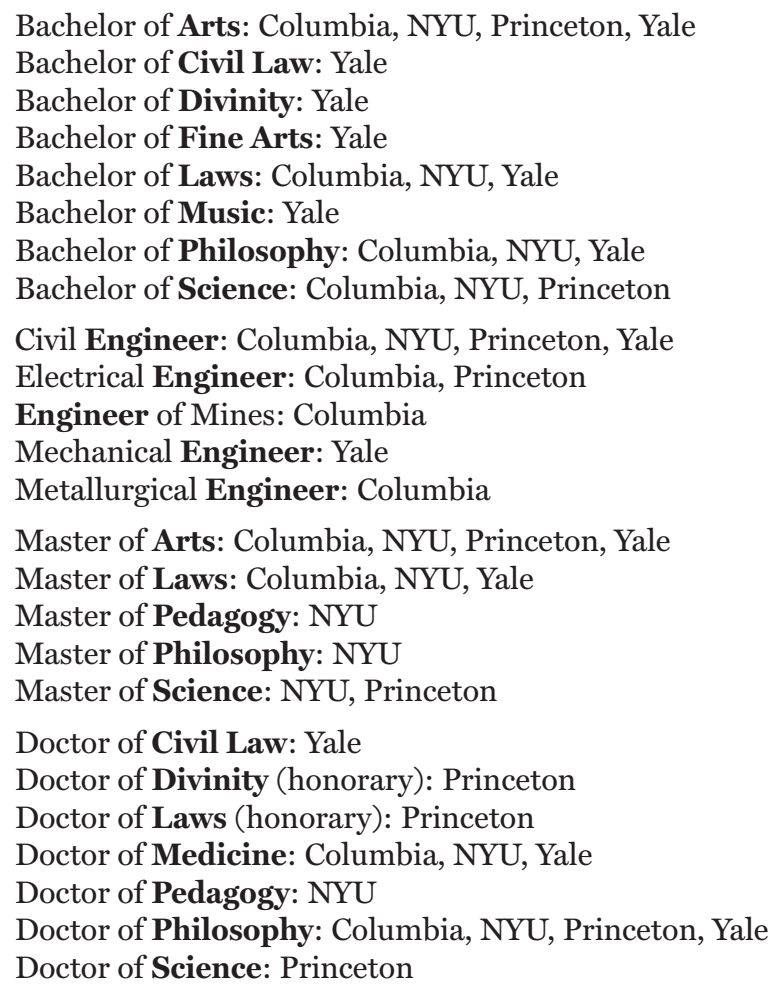

When one compares the list of degrees above with the eight degree titles approved by the Intercollegiate Commission, one can see exactly why the commissioners selected those eight degree titles - they are the titles of degrees that were being conferred by their schools.

The only degrees offered that were not granted a colour were those in Engineering and Pedagogy, and this is because Commission members evidently felt that Engineering degrees ought to be subsumed within Science and use gold yellow (see Fig. 5), ${ }^{14}$ and that Pedagogy degrees ought to be subsumed within Arts and Letters and use white (see Fig. $3) .{ }^{15}$

As for the colours selected-it helped to be the host of the Intercollegiate Commission. Columbia's faculty colours for Arts and Letters (white), Medicine (green), and Science (gold yellow) were carried over without change to the new Intercollegiate Code. ${ }^{16}$ None of NYU's existing colours were used, except for the yellow of Science and Engineering, and in the same way Engineering was folded into Science, NYU's Pedagogy was folded into the Arts and Letters of the Code, which was convenient because it, too, used white.

14 As it was in New York University's 1892 faculty colour scheme.

15 In 1895 the only Pedagogy degrees in the US were being conferred at NYU, and these were already using white as a faculty colour.

16 According to p. 14 of the Intercollegiate Bureau and Registry of Academic Costume, Bulletin 13 (Albany: Cotrell \& Leonard, 1898), in the establishment of a code of colors for trimmings to represent the faculty in which the degree is conferred,' the Intercollegiate Commission was 'ably assisted by Prof. Rood, of Columbia University, an acknowledged expert in chromatics.' 
Three folded hoods display different degree colours on the velvet or velveteen trim of each hood. To the left, a

c. 1929-35 Bachelor of Science hood by Cotrell \& Leonard (New York). In the center, a c. 2013 'graduation quality' Master of Physical Education hood by Academic Cap \& Gown (California). On the right, a c. 2007 'faculty quality' Doctor of Music hood by Jostens (Minnesota). Modern bachelors' hoods are in a simple shape and three feet long, with velvet trim two inches wide. Masters' hoods are also in a simple shape, but three and a half feet long and with velvet trim three inches in wide. Doctors' hoods are four feet long and resemble the full shape, with velvet trim five inches wide. One will notice that the master's hood above is not of the best quality: it is significantly shorter than the authorized length and lacks the crescent-shaped cutout on the hood's liripipe

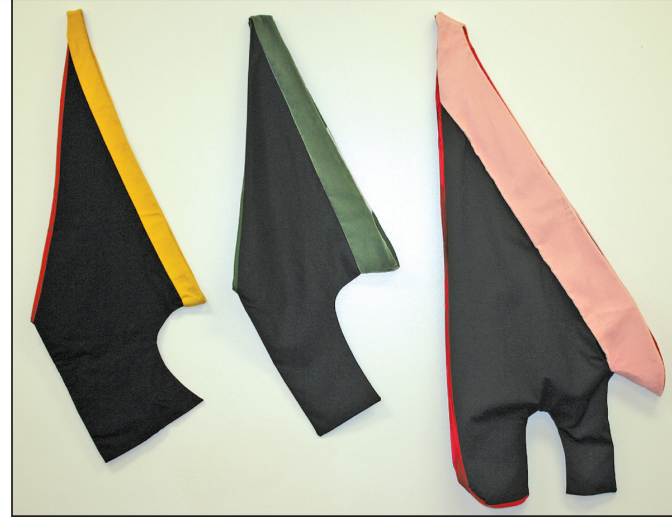

FIG. 1

that is traditionally used on US hoods, echoing the crescent-shaped cutout on the sleeves of the master's gown. This 'graduation quality' hood is intended to be a souvenir of the commencement ceremony, not one to be used professionally.

Left to right: collection of the author, Trini Rangel, and Charlotte Anderson.

\section{Arts and Letters: white \\ Medicine: green \\ Science: gold yellow}

The justification for retaining Columbia's faculty colours for Arts and Letters, Medicine, and Science seems to have been that they had symbolic, cultural, or historical associations with the disciplines they represented. For instance, all three degree colours had European roots. White was chosen as the colour for Arts and Letters because it was the colour of the fur edging on Oxford and Cambridge Bachelor of Arts hoods, the gold yellow ${ }^{17}$ of Science may derive from the gold faculty colour of the University of London Bachelor of Science and Doctor of Science degrees (or from any number of German universities that also used gold for Science in the nineteenth century), and green may have been selected for Medicine because several German universities used it as the faculty colour for Medicine at that time. ${ }^{18}$ As many American professors would have had degrees from these institutions, or would have looked to these institutions as representing the crème de la crème of collegiate education, their faculty colour choices would have seemed worthy of emulation.

17 Later, 'golden yellow' starting in 1936. See The History of Academic Costume in America, pp. 10-11.

18 Bruce Christianson, 'Lined with Gold: London University and the Colour of Science', TBS, 5 (2005), pp. 86-87. See also T. W. Wood, The Degrees, Gowns, and Hoods of the British, Colonial, Indian, and American Universities and Colleges (London: Thomas Pratt \& Sons, n.d. but c.1883), p. 10. 
Symbolically, green was the colour of 'the stripe in the [US] army surgeon's uniform,' ${ }^{19}$ and it is the verdant colour of life and growth, traditionally symbolizing good health. ${ }^{20}$ There were also multiple symbolic and cultural reasons to retain gold yellow for Science. Gold symbolizes the wealth of knowledge that has been derived from scientific endeavours, ${ }^{21}$ and in medieval alchemy the heraldic tincture $\mathrm{Or}$ (gold or yellow) was associated with the improvement of one's intelligence. Another explanation for this colour choice is that the origin of modern science is in alchemy, which sought the Philosopher's Stone that would change base metals into gold.

\section{Law: purple}

\section{Theology: scarlet}

The new degree colours chosen by the Intercollegiate Commission that were not used at Columbia or NYU were 'in part arbitrary, [though] suggested very generally by associations either historic or imaginative, which may or may not seem happily significant to the investigator.'. ${ }^{22}$ Purple is a symbol of royalty and the legal and political power therein ${ }^{23}$ and was also a colour medieval alchemists associated with justice, making it an appropriate choice for degrees in Law. ${ }^{24}$ The scarlet of Theology 'has often been held symbolic of the blood of Christ or the robe he wore just before his crucifixion (Matthew 27.28), ${ }^{25}$ so in Christianity scarlet has come to signify 'ardent love and zeal for the faith'. ${ }^{26}$

\section{Philosophy: dark blue}

Some German universities used blue as the faculty colour for Philosophy, ${ }^{27}$ and since the American PhD is of German origin (imported to the US in 1861 by Yale University), it is possible that American universities may have borrowed the blue colour of Philosophy from the Germans as well. In the late nineteenth and early twentieth centuries there was 'a large number of Professors in the United States of America and elsewhere holding German de-

19 'Albany Bureau of Academic Costume: Caps, Gowns and Regalia for American Colleges Originate Here', The (Albany, N.Y.) Argus, 27 July 1902. Beginning with the 1872 Regulations for the Uniform and Dress of the Army of the United States, military hospital stewards wore collar facings, shoulder straps, chevrons, and trouser stripes in emerald green.

20 David A. Lockmiller, Scholars on Parade (New York: Macmillan, 1969), p. 186. Most early-twentieth-century sources also note that green is the colour of the herbs and plants that were used in ancient medicine, but this is a symbolic association more fitting for Pharmacy, discussed later.

21 'Albany Bureau of Academic Costume: Caps, Gowns and Regalia for American Colleges Originate Here'. Hereafter 'Albany Bureau ... Caps, Gowns'.

22 Raymond MacDonald Alden, 'Academic Ceremonial', The Independent, 67.3180 (11 November 1909), p. 1074.

23 'Albany Bureau ... Caps, Gowns'.

24 This faculty begins to be listed in Intercollegiate Bureau of Academic Costume materials as 'Laws' around 1903. See Concerning Caps, Gowns and Hoods, Bulletin 17 (c. 1902), p. 13. This likely reflects the existence of Civil Law and Canon Law degrees as well as the actual title of most Law degrees (Bachelor of Laws, Master of Laws, Doctor of Laws), or perhaps it was meant to suggest the inclusion of degrees in Political Science or Government like the Master of Diplomacy degree that was being conferred by the Department of Jurisprudence and Diplomacy at George Washington University during this period.

25 Lockmiller, p. 186.

26 'Albany Bureau ... Caps, Gowns'.

27 Christianson, p. 86. 
grees $^{28}$ so it makes sense that this colour would have been associated with the PhD. The association of blue ${ }^{29}$ with Philosophy is made stronger because blue is a symbol of truth and wisdom..$^{30}$ This is because blue is the colour of the sky, which has traditionally symbolized the ethereal qualities of human emotion, imagination, intellect, and creativity: when clouds dissipate, the clear sky is revealed. ${ }^{31}$

Fine Arts: brown

Music: pink

The pink of Music is derived from the Oxford DMus hood used in the 1890s, which was cream brocade with a pink lining. ${ }^{32}$ And although an early source says that brown was adopted for Fine Arts in an 'arbitrary fashion without reference to historic significance or any particular appropriateness, ${ }^{33}$ russet brown was the faculty colour for the Bachelor of Arts and Master of Arts degrees at the University of London, which since 1871 had been the home of the Slade School of Art, one of the most prestigious fine arts schools in the world. ${ }^{34}$ Brown was also the base colour of various earthen pigments used in the earliest prehistoric paintings, and bistre-similar to the dark blackish-brown shade found on most vintage Fine Arts hoods ${ }^{35}$-is the colour of the drawing charcoal used by artists since ancient times.

These eight degree colours remained the only official colours recognized by the Intercollegiate Bureau until at least February $1898 .^{36}$

\section{The first decade (1895-1905): New registrants, degrees, and colours}

The 1895 Intercollegiate Code of Academic Costume proved to be popular and was quickly adopted by many of the colleges and universities in the United States, including most of the major universities such as California, Chicago, Columbia, Cornell, Dartmouth, Harvard (after 1902), Johns Hopkins, Michigan, Minnesota, Pennsylvania, Princeton, Wisconsin, and Yale as well as smaller, selective private universities in the north-east such as Amherst, Barnard, Bryn Mawr, Lehigh, Radcliffe, Wellesley, Wells, and Williams. In numbers

28 Frank W. Haycraft, The Degrees and Hoods of the World's Universities and Colleges (Ware: Jennings \& Bewley, 1923), p. 52.

29 The Intercollegiate Code of Academic Costume listed the colour as dark blue but the Intercollegiate Bureau of Academic Costume listed the colour as blue. 'Blue' was repeated in catalogues from Cotrell \& Leonard but oddly, vintage gowns and hoods from this company employ dark blue velvet trim. 'Dark blue' was designated by the American Council on Education starting in 1935 and this description has continued to be used to the present day. See Frederick C. Ferry, 'An Academic Costume Code', The Educational Record (July 1935; reprint Washington, D.C.: American Council on Education, 1935), p. 5.

30 'Albany Bureau of Academic Costume: Caps, Gowns and Regalia for American Colleges Originate Here'.

31 Lockmiller, p. 186.

32 A 1902 article incorrectly states that this faculty colour reflects the 'pink brocade' [sic] on the Oxford Doctor of Music gown [sic]. See 'Albany Bureau ... Caps, Gowns'.

33 'American Cap, Gown, and Hood', Sigma Kappa Triangle, 3.4 (July 1909), p. 263.

34 Wood, p. 10. Bruce Christianson first suggested this link in 'Lined with Gold', p. 86.

35 See, for instance, 'Speaking of Pictures ... Hoods Tell Degree, College, and Field of Study', Life (16 Oct. 1950), pp. 20-21.

36 Intercollegiate Bureau and Registry of Academic Costume, Bulletin 13 (Albany: Cotrell \& Leonard, 1898), p. 15. This catalogue had been published by February of that year, see the 'Intercollegiate Bureau and Registry of Academic Costume' advertisement, The School Journal, 56.9 (26 February 1898), p. 226. 
that suggest how popular the Code had become, nearly 150 institutions were following its stipulations within six years of its creation. ${ }^{37}$

On 2 July 1902 the Regents of the University of the State of New York granted a charter ${ }^{38}$ to the 'Intercollegiate Bureau of Academic Costume', ${ }^{39}$ affiliated since 1887 with the Albany academic costume firm of Cotrell \& Leonard. The Regents were responsible for accrediting all of the educational institutions incorporated in the State of New York (primary, secondary, and collegiate), and was not (as the title suggests) a university proper. The charter granted to the Intercollegiate Bureau was ${ }^{40}$

to establish and maintain a library related to the universities, professional, technical and advanced schools and colleges of the world, particularly as to their membership and their ceremonial and other public appearances, including their gowns, hoods, caps, robes, badges, banners, arms and other regalia used on such occasions; to maintain a register of statutes, codes and usages, designs and descriptions of the articles of academic costume and regalia with their correct colors, materials, qualities, sizes, proportions and the arrangement thereof; to promote social intercourse among members of universities and colleges and to disseminate information on the subjects above mentioned.

At a minimum this meant that the Bureau needed to assign colours to all of the genres of degrees being offered by institutions of higher learning in New York, and in 1901 the Regents had approved the following degrees for use by colleges and universities in that state: ${ }^{41}$

\author{
Bachelor or Master of Arts \\ Bachelor, Master, or Doctor of Dental Surgery \\ Bachelor or Doctor of Divinity; Doctor of Sacred Theology \\ Civil, Electrical, or Mechanical Engineer \\ Bachelor, Master, or Doctor of Laws; Doctor of Civil Law \\ Bachelor, Master, or Doctor of Library Science \\ Bachelor, Master, or Doctor of Literature; Doctor of Humane Letters \\ Bachelor or Doctor of Medicine \\ Bachelor or Doctor of Music \\ Bachelor or Doctor of Pedagogy \\ Bachelor, Master, or Doctor of Philosophy \\ Certified Public Accountant \\ Bachelor, Master, or Doctor of Science \\ Bachelor or Doctor of Veterinary Surgery
}

37 'School Equipment: Graduation Gowns', The School Journal, 62.22 (1 June 1901), p. 603.

38 University of the State of New York College Department Fifth Annual Report: 1902 (Albany: University of the State of New York, 1903), p. r4 (the 'r' stands for Report). The Regents of the University of the State of New York are not to be confused with the institutions that enroll students called the State University of New York.

39 As chartered, the Bureau dropped 'and Registry' from its original title, but advertisements for the Cotrell \& Leonard firm used both the long and short title of the Bureau interchangeably for the next decade.

40 'Albany Bureau ... Caps, Gowns'.

41 115th Annual Report of the Regents [of the University of the State of New York] 1901: Administrative Department (Albany: University of the State of New York, 1902), p. 271. Also University of the State of New York Regents Bulletin No. 59 (Albany: University of the State of New York, 1903), p. 25. 
FIG. 2

During the first few decades of the Intercollegiate Code, faculty who had earned more than one doctorate were permitted to divide the velvet trim on their hood and gown to display two or more degree colours. Here is a very rare example of one of these hoods (c. 1890s-1920s?) from a professor who held $\mathrm{a}$ PhD and a DD degree, signified by the dark blue and scarlet velvet trim of the hood.

The practice was prohibited by the 1935 Academic Costume Code as 'bad form', adding that 'the imagination dislikes to contemplate the results to which such a proposal might lead if, as often happens, the wearer held doctorates in three or more subjects'.

The white lining of the hood represents the colour of the institution that conferred the degree or (as here) the institution at which the professor was employed-probably Bowdoin College (Maine) or perhaps Smith College (N.Y.). Author's collection.

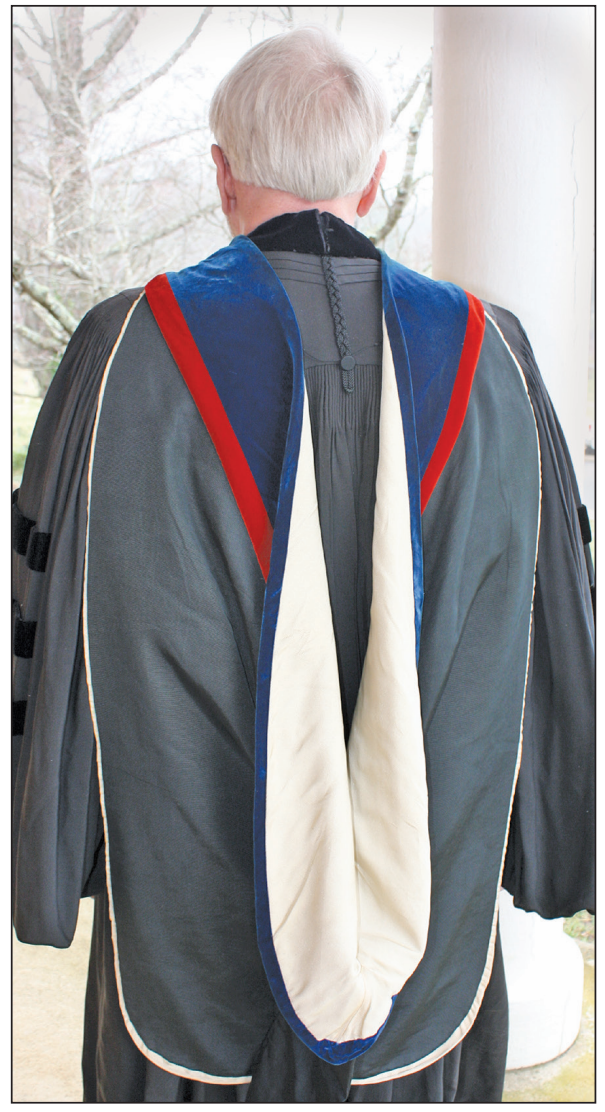

This list does not include diplomas or licences from the handful of Pharmacy or Ophthalmology schools the Regents accredited. ${ }^{42}$ Of these degrees and diplomas, Dental Surgery, Engineering, Library Science, Ophthalmology, Pedagogy, Pharmacy, Public Accountancy, and Veterinary Surgery had not been granted degree colours in the 1895 Intercollegiate Code. As we have seen, the 1895 Intercollegiate Commission tended to think of the eight official degree colours in rather broad terms and considered Engineering and Pedagogy to be subsumed by the degree colours for Science and Arts and Letters, respectively. But this decision was reevaluated in the early 1900s as the Intercollegiate Bureau moved to assign colours to most of these degree title categories the Regents of the University of the State of New York had approved for institutions of higher learning in the state.

Additionally, the Bureau was charged with registering the degree colours of institutions outside the State of New York. When colleges and universities participating in the Intercollegiate Code discovered that a degree they offered did not include one of the titles

42 For instance, beginning in 1904 the Doctor of Pharmacy degree would be conferred at the College of Pharmacy within Columbia University, as well as the traditional Graduate in Pharmacy Degree. See Columbia University Bulletin of Information, Series 4, No. 23: College of Pharmacy of the City of New York (New York: Columbia University, 25 June 1904), p. 5. 
in the Code (Science, Medicine, Arts, Letters, Fine Arts, etc.) the institution would typically select a colour for that degree and register that degree colour with the Intercollegiate Bureau, or request help from the Bureau in selecting a colour for the degree. However, the Bureau did not necessarily follow the lead of the university and adopt colours for these new degrees because as I have pointed out at this early point in its history the Bureau seems to have preferred to consider the degree colour categories to be general and inclusive.

Nevertheless, an 1898 list of university degrees cites a number of American degree titles that are not to be found in the official degree colour list of the Code: ${ }^{43}$

Bachelor or Master of Accounts
Bachelor or Master of Agriculture
Bachelor of Agricultural Science
Bachelor or Master of Scientific Agriculture
Bachelor or Master of Architecture
Bachelor or Master of Business Science
Bachelor of Chemical Science
Analytical Chemist
Practical Chemist
Pharmaceutical Chemist
Bachelor or Doctor of Chemistry
Bachelor or Doctor of Civil Law
Bachelor of Commerce
Bachelor of Commercial Science
Doctor of Dental Medicine
Master or Doctor of Dental Surgery
Bachelor of Didactics
Master of Elementary Didactics
Bachelor or Master of Scientific Didactics
Bachelor or Doctor of Divinity
Master of Domestic Economy
Master of Elements
Bachelor of Elocution
Chemical Engineer
Civil Engineer
Dynamical Engineer

\author{
Electrical Engineer \\ Irrigation Engineer \\ Mechanical Engineer \\ Metallurgical Engineer \\ Engineer of Mines \\ Sanitary Engineering \\ Topographical Engineering \\ Bachelor of Scientific Forestry \\ Master of Horticulture \\ Licentiate of Instruction \\ Bachelor, Master, or Doctor of Library Science \\ Doctor of Mathematics \\ Doctor of Natural History \\ Doctor of Natural Science \\ Bachelor, Master, or Doctor of Oratory \\ Bachelor or Master of Painting \\ Master or Doctor of Pharmacy \\ Graduate in Pharmacy \\ Master of Polite Literature \\ Bachelor of Sacred Theology \\ Doctor of Veterinary Medicine \\ Doctor of Veterinary Science \\ Doctor of Veterinary Surgery \\ Veterinary Physician \\ Veterinary Surgeon
}

Some of the degree titles on this list are synonymous: degrees in 'Didactics', 'Elements', 'Instruction', or 'Pedagogy' were degrees in Education. I have already noted that Pedagogy was not included in the 1895 Code and so these degrees would have presumably used the white of Arts and Letters. Other degrees on this list also might be considered subdivisions of a faculty already included in the Code. For instance, among degrees in Science, gold yellow would obviously be the degree colour for a Doctor of Science, but in the list above it would likely be used for a Doctor of Chemical Science, Doctor of Chemistry, Doctor of Mathematics, Doctor of Natural History, and Doctor of Natural Science. Likewise, the College of Fine Arts at Syracuse University conferred Bachelor of Painting, Master of Painting, Bachelor of Architecture, and Master of Architecture degrees at the turn of the

43 Flavel S. Thomas, A Dictionary of University Degrees (Syracuse: C. W. Bardeen, 1898). See also Edwin Emerson, ed., The College Year-Book and Athletic Record for the Year 1896-7 (New York: Stone \& Kimball, 1897), pp. 443-47. I have removed the degree titles precisely covered by the Code, like Bachelor of Arts, Master of Science, Doctor of Theology, and so on. 
century, but the Intercollegiate Bureau never adopted a degree colour for Painting or Architecture because the Bureau evidently considered these to be types of 'Fine Arts' degrees, using brown for all. ${ }^{44}$

However, for historical or pedagogical reasons other degrees were less easy to slot into the existing degree colours of the Code. A few examples come to mind. For instance, why did the Intercollegiate Commissioners not place Music degrees within 'Fine Arts' brown in 1895? Later, did the Intercollegiate Bureau consider the Bachelor of Agriculture to be a science degree? And is the Doctor of Dentistry a medical degree, or should it receive a separate degree colour?

After the Commission made its initial selection of the first eight degree colours, universities and the Intercollegiate Bureau tried to address these kinds of questions and suggest new degree colours if needed. Universities and the Bureau did not always arrive at the same answer to these questions, but a stronger case could be made for a new degree colour if the faculty conferring the (self-titled) degree was a large academic unit like a college or school within the university or separate from it, like a school of music, agricultural institute, or college of Dentistry.

\section{Veterinary Science: grey Dentistry: lilac}

The ink wasn't dry on the 1895 Code before institutions that had not been part of the Intercollegiate Commission began to request additions to the degree colour list. For instance, the University of Pennsylvania immediately adopted the Code with the addition of two new degree colours-lilac for their degrees in Dentistry and grey (also described as 'steel-gray') for their degrees in Veterinary Medicine-because these 'faculties had no colours assigned to them-indeed were not mentioned at all-in the intercollegiate system as originally proposed to the universities; nor had these colours been appropriated to indicate any other faculties in the general colour scheme. 45

Why the University of Pennsylvania selected these colours is unknown. A 1909 article says that the grey of Veterinary Science and the lilac of Dentistry were chosen in an 'arbitrary fashion without reference to historic significance or any particular appropriateness.' ${ }^{46}$ Pennsylvania already had a faculty colour system in place when the 1895 Code was adopted, and the previous faculty colour for Veterinary Medicine in that system was cardinal. ${ }^{47}$ Because cardinal was similar in hue to the scarlet colour assigned to Theology in the 1895 Code another colour was needed. There were no other traditional primary colours remaining; orange was the only remaining secondary colour, and grey was the only remaining achromatic colour. Grey was chosen for reasons unknown, but it is tempting to think that

44 By the late 1920s, for example, the University of Pennsylvania was stipulating that brown was the colour for 'Fine Arts (including degrees in Architecture)'; see Catalogue of the University of Pennsylvania: 1928-1929 (Philadelphia: University of Pennsylvania, 1929), pp. 115-16. In 1935 the American Council on Education assigned brown to 'Fine Arts, including Architecture'. See Ferry, p. 5. This probably clarified what the Intercollegiate Bureau was already practising because nearly the same description is listed in O. J. Hoppner, Academic Costume in America (Albany: Cotrell \& Leonard, 1948), p. 14.

45 J. Hartley Merrick, 'Historical Sketch of Academic Costume Usage', University Bulletin [of the University of Pennsylvania], 3.8 (May 1899), pp. 302-03.

46 'American Cap, Gown, and Hood', p. 265.

47 Merrick, p. 300. 
Pennsylvania may have passed over orange and selected grey for Veterinary Medicine because it is a common colour of animal fur.

Previously the University had used pink for Dentistry, but once the Intercollegiate Code assigned pink to Music I assume the University selected lilac for Dentistry because it was an unassigned hue that was somewhat similar to the original pink. Pennsylvania's selection of lilac was communicated both to the Intercollegiate Bureau and to the National Association of Dental Faculties, and on 1 August 1896 at the 13th Annual Meeting of the Association, 'Mr. G. C. Leonard, of [the Intercollegiate Bureau in] Albany, was given permission to exhibit gowns and hats, illustrating the code, language, and significance of gowns, with a view of selecting a color for the dental profession.' A committee of three dentists was formed 'to select and recommend a distinctive color for the trimmings of academic costumes for the dental degree, ${ }^{48}$ and on 3 August 1896 the committee recommended lilac as the colour for dentistry and that the 'intercollegiate system' be adopted as academic costume. A motion from the floor recommended 'the colors of medicine and those proposed for dentistry be blended' but no specific hue was proposed. A final decision on this matter was postponed for one year. ${ }^{49}$

One month later, an editorial in The Dental Digest recommended the colour red,,$^{50}$ a suggestion that was impractical because it would create confusion with the official scarlet colour of Theology in the Code. So at the 1897 meeting of the National Association of Dental Faculties the matter was taken up again and on 30 July the members voted to make 'the standard lilac as the distinctive dental color' as well as to adopt the Intercollegiate academic costume system. ${ }^{51}$ This decision was communicated to the Intercollegiate Bureau, which started to add Dentistry's lilac to their list of official degree colours.

\section{Pedagogy: light blue}

Even though it had been a member of the Intercollegiate Commission, New York University had less success in having new degree colours added to the Bureau's register. On 3 June 1895 the University adopted the Code with 'an addition to the same being made on behalf of students wearing degrees in Pedagogy, which at this date are given by no other University'. To the list of degree colours in the Code, NYU added 'Pedagogy, French gray' ${ }^{52}$ It is unknown if NYU, which had been one of the participants in the Intercollegiate Commission, suggested this faculty colour to the rest of the committee, who were content to let Pedagogy degrees be represented by the white of Arts and Letters. Perhaps NYU did and were outvoted.

48 Proceedings of the National Association of Dental Faculties Thirteenth Annual Meeting (Chicago: National Association of Dental Faculties, 1896), p. 8. See also J. Edward Line, ed., The Odontographic Journal, 17.3 (Rochester: Rochester Dental Manufacturing Co., October 1896), p. 184.

49 Ibid,, p. 14.

50 The Dental Digest, 2.9 (September 1896), p. 543.

51 Proceedings of the National Association of Dental Faculties Fourteenth Annual Meeting (St. Louis: National Association of Dental Faculties, 1897), p. 9. It is interesting that they described lilac as the 'standard' colour for Dentistry, which implies that the lilac used at the University of Pennsylvania had become the colour of choice by other Dentistry programmes.

52 New York University: University Graduate School Announcements for 1896-1897 (New York: New York University, 1896), pp. 16-17. According to Webster's Dictionary, French grey is 'a light greenish gray that is bluer and duller than ash gray or lichen green'. 
At any rate, pedagogical degrees were increasingly conferred across the nation at a number of what were called 'normal colleges', i.e., colleges of pedagogy or education that could be independent state or private colleges or a constituent unit of larger state universities. ${ }^{53}$ No longer the only institution offering degrees in Pedagogy, NYU waited until 1903 to attempt to register French grey with the Intercollegiate Bureau. The Intercollegiate Bureau baulked at NYU's suggestion to assign French grey to Pedagogy because the Bureau did not want two faculties (Veterinary Medicine and Pedagogy) to use similar hues, and instead suggested that graduates in Pedagogy at NYU wear a light blue degree colour because it is a combination of the white of Arts and Letters and the blue of Philosophy (see Fig. 3). ${ }^{54}$ The Bureau probably added Pedagogy's light blue to the official degree colour list at this point. By 1910 NYU was using light blue for its graduates in Pedagogy and had reassigned French grey to Veterinary Medicine, (almost) per the Code. ${ }^{55}$

\section{Pharmacy: olive}

At the turn of the century the Bureau assigned the degree colour of 'olive' to Pharmacy. I do not know if a specific institution officially requested this addition to the list of degree colours, but I think it is likely that this decision was influenced by the fact that the Intercollegiate Bureau was located in Albany-home of the Albany College of Pharmacy.

A modern symbolic justification for this choice of colour is that olive recalls the dried herbs and plants used for medicinal purposes in ancient times, but a 1902 article says that olive was chosen because it is a colour close to the green of Medicine,${ }^{56}$ making it the second example (after Pedagogy) of the Bureau's preference to group similar faculties under the same basic hue. ${ }^{57}$

\section{Library Science: Iemon}

The 'lemon' of Library Science was no doubt chosen for corresponding reasons, being a shade similar to the gold yellow of Science. On 12 February 1891 the Regents of the University of the State of New York had approved three new Library Science degrees (Bachelor, Master, and Doctor of Library Science) to be conferred by the New York State Library School. ${ }^{58}$ These titles reflected the professional nature of the degrees and were conferred by a professional school and not by a liberal arts college or university. ${ }^{59}$

Personally, I find the colour description 'lemon' to be unsatisfying, as it falsely implies a symbolic or historical relationship between the fruit and Library Science (or at least a symbolic or historical relationship I have not been able to discover). 'Bright yellow' would

53 The name of universities for teachers in the US derives from L'École Normale Supérieure, Paris

54 See also 'American Cap, Gown, and Hood', p. 263, which states that Pedagogy 'has adopted a modification of the philosophy color'.

55 'Rules for Academic Costume', New York University Bulletin, 10.1 (January 1910), p. 21.

56 'Albany Bureau ... Caps, Gowns'.

57 This was not done with Dentistry, as lilac is not a shade of green. Perhaps the idea to group similar subjects under one colour was an idea that came to the Bureau after Dentistry's colour had already been selected.

58 Library School Register of New York State Library School, Bulletin 73 (New York: New York State Library, June 1902), p. 45.

59 Otherwise the degrees would have probably been titled 'Bachelor of Science in Library Science', or 'Master of Arts in Library Science', or something similar. 
FIG. 3

A 1903 letter from the Cotrell \& Leonard firm to the Chancellor of New York University regarding a suitable degree colour for Pedagogy. Archives of New York University. Courtesy Stephen Wolgast.

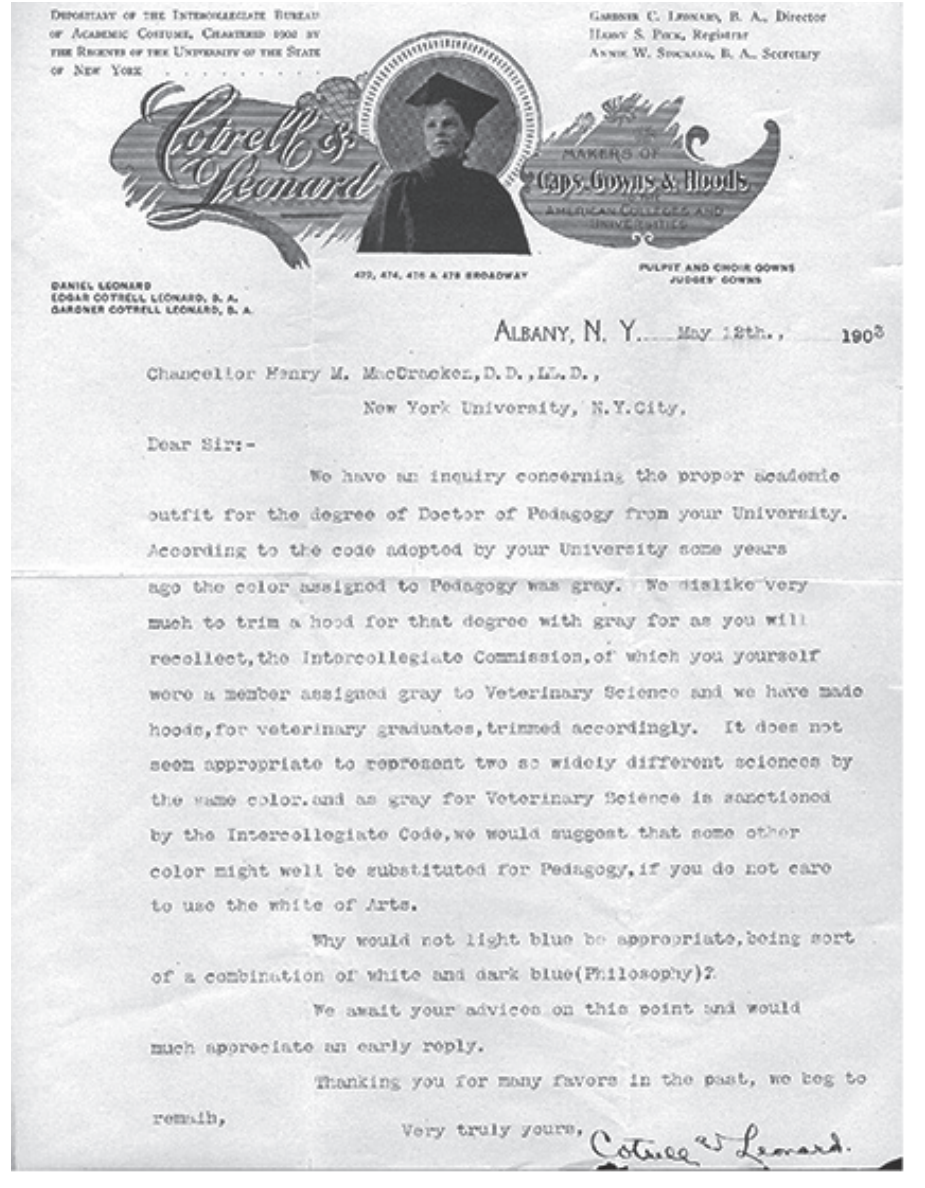

have been a better descriptor, as it is the colour of the sun, whose illumination has been a traditional symbol of the pursuit of knowledge and wisdom through study and inquiry.

\section{Forestry: russet}

Oddly missing from the above list of degrees conferred by New York institutions is the Bachelor of Scientific Forestry degree. The New York State College of Forestry at Cornell University opened in 1898 and was the first degree-granting Forestry programme affiliated with a university in the United States. It offered a Bachelor of Scientific Forestry four-year degree as well as a graduate-level professional certification (not a degree) called Forest Engineer ${ }^{60}$ Its first graduating class was in $1900,{ }^{61}$ the same year Yale began the first postgraduate programme in Forestry at the Yale Forest School, later the School of Forestry.

60 Announcement of the New York State College of Forestry at Cornell University 1898-99 (Ithaca: Andrus \& Church, 1898), pp. 20-22. See also James Lassoie, Raymond Oglesby, and Peter Smallridge, 'Roots of American Forestry Education: Trials and Tribulations at Cornell University', Forest History Today magazine, 1998. For the degree title, see Thomas, p. 39.

61 Ralph S. Hosmer, 'Forestry at Cornell', Cornell Forester, 1 (June 1920), p. 33. 
(Yale is not a New York institution but as you may recall it was a member of the 1895 Intercollegiate Commission.) Yale conferred its first Master of Forestry degree in $1902^{62}$ but the Cornell programme was defunded and closed in $1903 .{ }^{63}$

Although Forestry is arguably one of the Sciences, these new institutions must have requested a special degree colour from the Bureau, possibly because the degrees were conferred by academic units separate from the College of Arts and Sciences at Cornell and the Sheffield Scientific School at Yale. So by 1901 the Intercollegiate Bureau had approved 'russet' as the degree colour for Forestry. Russet was inspired by the clothing colour 'worn by jolly old English foresters who wore it in the fall as they quaffed their brown October ale', ${ }^{4}$ or-less loquaciously - the colour may simply have been intended to represent the colour of autumn foliage. ${ }^{65}$ Either way, the Bureau chose to assign a brown shade to a subject that was not one of the arts-a decision inconsistent with its recent attempts to create colour families for broad academic subjects. This suggests that russet may have been chosen first by a school and then reported to the Bureau for approval (as the non-medical/non-science family colours of lilac for Dentistry and grey for Veterinary Science had been by the University of Pennsylvania).

\section{Commerce and Accountancy: drab}

A 1909 article says that the lilac of Dentistry, the grey of Veterinary Science, the lemon of Library Science, and the drab of Commerce and Accountancy were chosen in an 'arbitrary fashion without reference to historic significance or any particular appropriateness. ${ }^{66} \mathrm{~A}$ wag might disagree that there is no association among Commerce, Accountancy, and 'drab'. Having both a pejorative name and an unattractive hue, this colour has been the butt of jokes for years, with Business professors commonly referring to it as 'baby-poo brown' or 'booger brown'. Drab is generally defined as a dull brownish grey colour or more specifically as a 'light olive brown' ${ }^{67}$ Today some universities use the terms 'beige', 'khaki', or 'taupe' to describe the shade, vainly trying to avoid the association of Business with a word that means something lifeless, unappealing, dull, or boring, but in the first half of the twentieth century Cotrell \& Leonard's interpretation of this colour was a darker, browner hue ${ }^{68}$

When the 1895 Intercollegiate Code was written there were a number of Business degrees being granted in the United States, including Bachelor of Accounts, Bachelor of Business Science, Bachelor of Commerce, Bachelor of Commercial Science, Master of Accounts, and Master of Business Science degrees, ${ }^{69}$ but none of these were conferred by the institutions that were part of the Intercollegiate Commission that drafted the Code. However, after New York University started a School of Commerce, Accounts, and Finance and

62 At <http://www.yale.edu/about-yale/president-leadership/governance-historic -documents /misc-regulations-yale-corporation\#degrees>, accessed 14 June 2016.

63 Samuel T. Dana, 'Education in Forestry', in Trees: The Yearbook of Agriculture (Washington: US Government Printing Office, 1949), pp. 655-56.

64. 'Albany Bureau ... Caps, Gowns'.

65 Lockmiller, p. 186.

66 'American Cap, Gown, and Hood', p. 263.

67 Webster's Third New International Dictionary, s.v. 'drab'.

68 Which was unfortunately similar in hue to the browns of Fine Arts, Forestry, and later, Economics. This probably explains why manufacturers today have shifted the hue of drab to a more distinctive-if less attractive-shade of light brownish grey.

69 Thomas, A Dictionary of University Degrees. 
began conferring Bachelor of Commercial Science degrees in 1902, it was not long before the Bureau added 'Commerce and Accountancy ${ }^{70}$ to its list of degree colours and assigned to it the aforementioned 'drab', which has been universally despised ever since.

This dissatisfaction has led to a couple of notable defections from the use of drab to indicate degrees in Business. Harvard currently uses 'medium gray' for its Master of Business Administration degree. ${ }^{71}$ More significantly, dozens of institutions today use 'sapphire blue', possibly following the lead of the University of Pennsylvania, home of the Wharton School of Business, the first business school in the United States. Pennsylvania began awarding Bachelor of Philosophy degrees with a 'Certificate of Proficiency in Finance and Economy' in $1884 . .^{72}$ At that time the faculty colour for the Bachelor and Doctor of Philosophy degrees at the Pennsylvania was sapphire blue. ${ }^{73}$ Pennsylvania began conferring Master of Business Administration degrees in 1921 but until at least 1937 the University did not designate a special colour for the MBA degree..$^{74}$ Catalogues from the 1920 s and 30 s do not indicate what colour its MBA graduates used, and I have not been able to determine when or why the University started using sapphire blue, but I suspect that there is a correlation between the sapphire blue of Pennsylvania's original 'Bachelor of Philosophy degree with a Certificate of Proficiency in Finance and Economy' and the sapphire blue of Pennsylvania's later 'Master of Business Administration' degree. ${ }^{75}$ The adoption of this colour may have occurred in the late 1960s or early 1970s, because the 1973 edition of the Academic Costume Code permits sapphire blue as an 'alternate' to drab, but it is 'not recommended because of the likely confusion with blues previously assigned to other subjects. ${ }^{76}$ This begrudging permission to use sapphire blue remained in the Academic Costume Code until the 1987 edition, after which drab has been the only colour permitted for 'Commerce, Accountancy, Business'. Nevertheless, colleges and universities such as Pennsylvania, Yale, Alaska, Memphis, Calgary (Canada), Western Michigan, Brigham Young, William \& Mary,

70 Between 1936 and 1948 the Intercollegiate Bureau changed the title to 'Business Administration, Commercial Science'. See Hoppner, p. 14. It is listed as 'Business Administration, Commerce' in a 1949 E. R. Moore catalogue. See Helen Walters, The Story of Caps and Gowns, 3rd printing (Chicago: E. R. Moore, 1949), p. 18. Since the 1960 printing of the Academic Costume Code, the discipline title has been conflated to 'Commerce, Accountancy, Business'. See Mary Irwin, ed., American Universities and Colleges, 8th edn (Washington: American Council on Education, 1960), p. 1135.

71 Harvard's Veterinary programme - which had closed in 1901-assigned grey to veterinary graduates as late as 1904, according to G. P. Baker, 'The Spring Term', The Harvard Graduates' Magazine, 11.44 (June 1904), p. 542. Harvard's MBA programme started in 1908, but it is not clear if the institution simply reassigned grey from the defunct Veterinary programme to the new Business programme, or if the institution's use of grey for Business was simply a coincidence.

72 Seep.7ofthe1985CommencementNotes, at<www.archives.upenn.edu/primdocs/upg/upg7 /upg7_1985_notes.pdf>, and p. 4 of the 1894_Commencement Program, at <www.archives.upenn.edu /primdocs/upg/upg7/upg7_1894june5.pdf>, both accessed 6 June 2016.

73 University of Pennsylvania One Hundred and Thirty-Third Annual Commencement Program (5 June 1889), p. 1, at <www.archives.upenn.edu/primdocs/upg/upg7/1889jun05prog.pdf>, accessed 6 June 2016.

74 See, for instance, Catalogue of the University of Pennsylvania: 1936-1937 (Philadelphia: University of Pennsylvania, 1937), p. 183.

75 I realize that correlation does not equal causation, but the specific use of 'sapphire' blue by both degrees seems to be more than just a coincidence.

76 W. Todd Furniss, ed., American Universities and Colleges, 11th edn (Washington: American Council on Education, 1973), p. 1756. Also American Council on Education, American Universities and Colleges, 12th edn (New York: Walter de Gruyter, 1983), p. 2069. 
FIG. 4

The cover of Concerning Caps, Gowns and Hoods, Bulletin 24, which was probably published in 1909. These annual catalogues contain photographs of the academic and clerical gowns manufactured by Cotrell \& Leonard as well as basic information about the Intercollegiate Code, including authorized degree colours. At this late date Cotrell \& Leonard was still referring to itself as the depository of the 'Intercollegiate Bureau and Registry of Academic Costume' [italics mine] instead of the shorter title under which the organization was chartered. Since the archives of the Bureau are evidently no longer in existence, annual catalogues like this are helpful in estimating the adoption dates for degree colours, but they are relatively uncommon and are difficult to find. Author's collection.

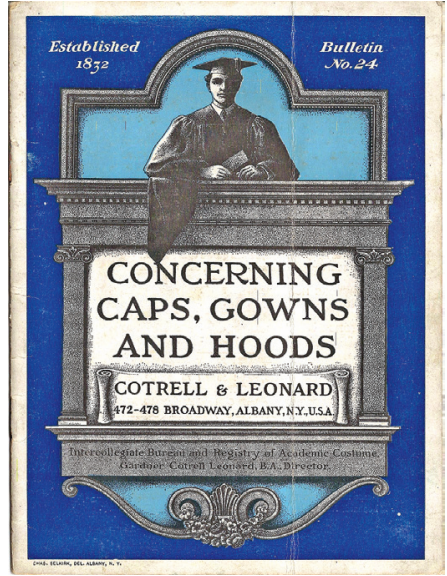

Colorado, and many others today continue to use sapphire blue in (understandably) brazen rebellion against drab.

As archival documents from the Intercollegiate Bureau are not available, at this point we cannot know the exact date each of these seven new degree colours was added to the Bureau's register. But catalogues from Cotrell \& Leonard (the depository of the records of the Intercollegiate Bureau) and other contemporary sources indicate that Dentistry was added between 1898 and 1901,77 Pharmacy and Veterinary Science were added in 1901; ${ }^{78}$ Library Science was added during 1901 or early $1902 ;{ }^{79}$ Pedagogy was added in $1903,{ }^{80}$ and Commerce and Accountancy were added at some point between 1903 and early $1905 .{ }^{81}$

\section{The second decade (1905-15): Interdisciplinary degrees and additional professional degrees}

By the end of the first decade of the twentieth century these were the principal degrees being conferred in the United States: ${ }^{82}$

77 'School Equipment: Graduation Gowns', The School Journal, 62.22 (1 June 1901), p. 603.

78 Concerning Caps, Gowns and Hoods, Bulletin 16, p. 13. Also New International Encyclopaedia, 1902 edn, s.v. 'degree'.

79 Concerning Caps, Gowns and Hoods, Bulletin 17, p. 13. Also Nerw International Encyclopaedia, ibid., as well as 'Albany Bureau ... Caps, Gowns'.

80 Letter from Cotrell \& Leonard to NYU Chancellor Henry M. MacCracken (12 May 1903), which is Fig. 3 in this essay.

81 Concerning Caps, Gowns and Hoods, Bulletin 20, p. 13.

82 This compilation of degrees comes from Report of the Commissioner of Education for the Year Ended June 301907 (Washington: Government Printing Office, 1908), Vol. II, pp. 739, 757-60. Additional charts are for 'professional schools' of medicine, dentistry, veterinary, pharmacy, theology, and law. As an indication of the pedagogical thinking of the time, it is worth noting that 'technological schools' are included in 'universities and colleges' but 'agricultural and mechanical schools', 'commercial and business schools', 'nursing schools', and 'normal schools' are not. Also see 'Degrees', in A Cyclopedia of Education, Vol. I, p. 286, which states that the bachelor's degree normally takes 
Bachelor or Master of Accounts

Bachelor of Agriculture

Bachelor or Master of Scientific Agriculture

Bachelor or Master of Architecture

Associate, Bachelor, or Master of Arts

Civil Engineer

Bachelor, Master, or Doctor of Civil Engineering

Bachelor or Master of Commercial Science

Doctor of Medical Dentistry

Bachelor of Didactics

Master of Diplomacy

Bachelor or Doctor of Divinity

Bachelor of Education

Electrical Engineer

Bachelor or Master of Electrical Engineering

Bachelor or Doctor of Engineering

Bachelor of Fine Arts

Master of Forestry

Licentiate of Instruction

Doctor of Law

Bachelor, Master, of Doctor of Laws

Doctor of Civil Law

\author{
Doctor of Civil and Canon Law \\ Bachelor or Master of Letters \\ Doctor of Humane Letters \\ Doctor of Literature \\ Master of English Literature \\ Bachelor of Library Science \\ Mechanical Engineer \\ Bachelor or Master of Mechanical Engineering \\ Doctor of Medicine \\ Metallurgical Engineer \\ Engineer of Mines \\ Bachelor, Master, or Doctor of Music \\ Bachelor of Oratory \\ Bachelor of Painting \\ Bachelor, Master, or Doctor of Pedagogy \\ Bachelor, Master, or Doctor of Philosophy \\ Licentiate in Philosophy \\ Bachelor, Master, or Doctor of Science \\ Master in Surgery \\ Doctor of Sacred Theology \\ Doctor of Veterinary Medicine \\ Veterinary Surgeon
}

While some of these degree titles would obviously use colours already in the Bureau's list (white for Bachelor of Arts), synonymous titles would use the same colour (light blue for Licentiate of Instruction, Bachelor of Didactics, Bachelor of Education, and Doctor of Pedagogy), and some degrees would be subsumed by existing degree colours (the brown of Fine Arts for Bachelor of Painting or Master of Architecture), it is not clear whether some of the degrees on this list ought to be subsumed under existing categories or receive new degree colours. During this period the Bureau seems to have been more inclined to assign a new degree colour to a degree if it was conferred by an institute, college, or school of that title that was within a larger university or was a respected pedagogical institution of that title that was independent of a university.

With the Intercollegiate Bureau almost doubling the Intercollegiate Code's original list of degree colours by the beginning of 1905, nearly all of the unique degree titles from this list have been accommodated. Only Agriculture, Architecture, Diplomacy, Engineering, Oratory, and Painting remain, and most of these could have been easily subsumed within an existing degree colour: 'Arts and Letters' (white) for Oratory; 'Fine Arts' (brown) for Architecture and Painting; 'Laws' (purple) for Diplomacy; 83 and 'Science' (gold yellow) for

four years, a master's degree one year more, and a doctor's degree two or three years more after the Master's degree.

83 Master of Diplomacy programmes were proposed as a course of Law School study in Charles W. Needham, 'Schools of Law: The Subjects, Order and Method of Study', in Report of the 21st Annual Meeting of the American Bar Association (Philadelphia: Dando, 1898), pp. 630-32. A Master of Diplomacy degree was offered in Columbian University's (called George Washington University starting 1904) Department of Jurisprudence and Diplomacy beginning in 1898; see John Barrett, 'An American School of Diplomacy', Harper's Weekly, 44.2254 (3 March 1900), p. 194; also The George Washington University Bulletin, 3.4 (December 1904), p. 116. But the pedagogical association of Diplomacy with Law was in flux at this time, and in 1905 the department was split into the Department of Law and Jurisprudence and the Department of Politics and Diplomacy, with the 


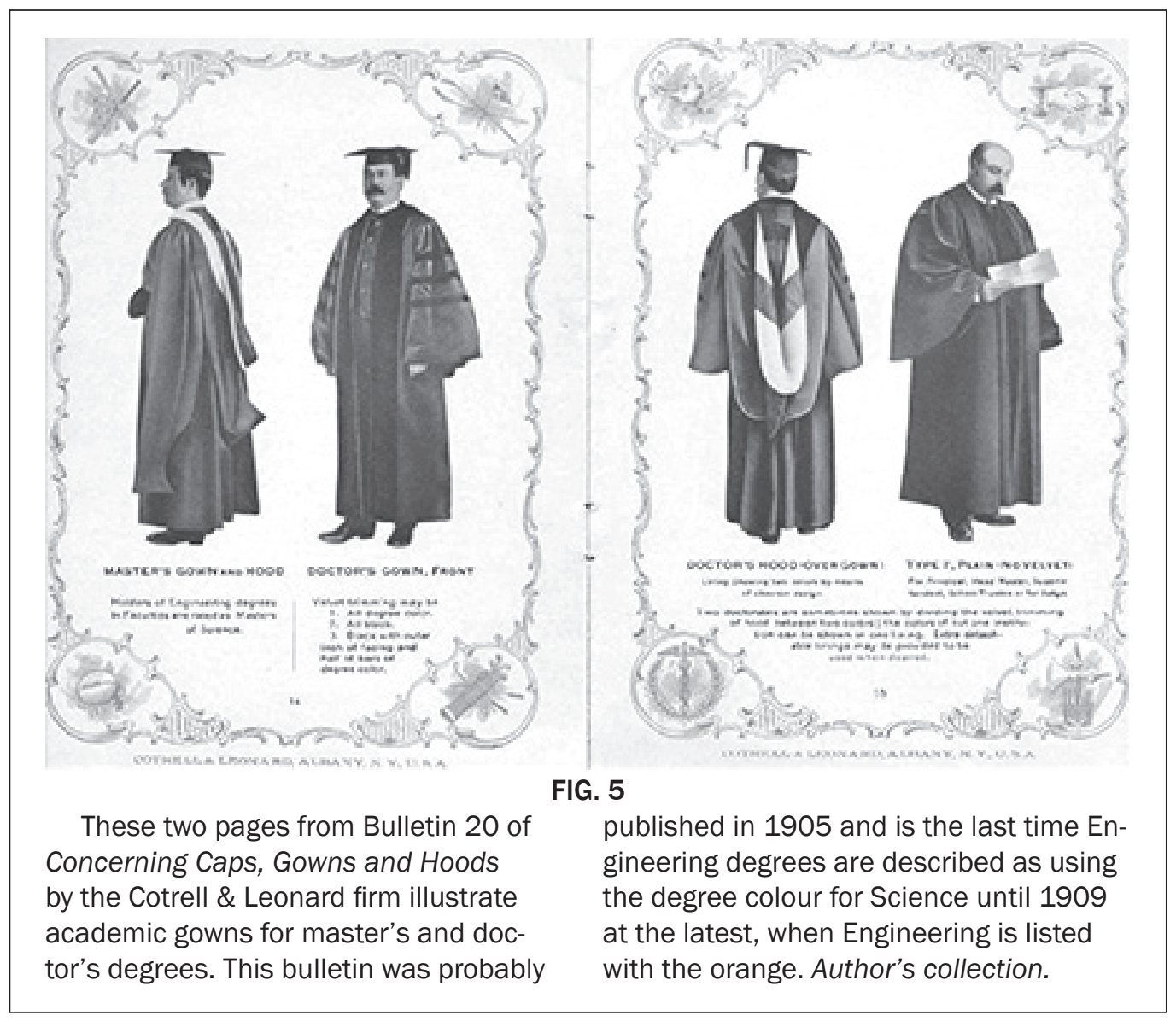

Agriculture and Engineering. Within a decade, however, the Bureau would change its mind and grant new degree colours for all of these except Architecture, Painting, and Diplomacy.

\section{Agriculture: maize}

\section{Engineering: orange}

With the number of Morrill Act land-grant colleges conferring degrees in 'such branches of learning as are related to agriculture and the mechanic arts', ${ }^{84}$ Agricultural and Engineering programmes were flourishing at the turn of the century. I assume that-as with degrees in Engineering-degrees in Agriculture and Horticulture used the gold yellow of Science. But on 2 December 1902 Harvard University adopted 'Golden brown' as the faculty colour

latter conferring the Master of Diplomacy degree; see The George Washington University Bulletin, 4.1 (1905), pp. 16-17 and 173-77.

84 U.S. Code, Title 7, Chapter 13, Sub-chapter i, § 304. The Morrill Act of 1862 and the Morrill Act of 1890 (also known as the Agricultural College Act of 1890) provided federal land to be used by each state to establish universities with an emphasis on agriculture, technology, engineering, military science, and the 'classics'. See Wolgast, 'The Intercollegiate Code', pp. 9-10. 
for its degrees in Agriculture, ${ }^{85}$ and this was probably the inspiration for the inclusion of this degree colour by the Intercollegiate Bureau, under the more poetic (and American) description of 'maize'.

Maize is the name used to describe 'Indian corn', a staple agricultural crop native to the Americas, but 'the color calls to mind [other types of] ripe grain'. ${ }^{86}$ There are actually many colours of maize, including white, yellow, brown, red, blue, and every shade in between. But as a description of a colour, 'maize' is usually defined as a light yellow, which is probably the hue the Bureau had in mind, as it is a shade of the yellow colour family the Bureau had assigned to the sciences. Most academic hoods for Agriculture degrees since the 1930s at the latest have used a light yellow colour and not the golden brown originally used at Harvard (see Fig. 6 for an example from 1938).

With the plethora of Engineering degrees and certifications being offered by colleges, universities, and technical schools it also was inevitable that a degree colour for Engineering would be requested that was distinct from the gold yellow of Science.

At its 1905 annual convention on 29 June, the Society for the Promotion of Engineering Education recommended that the colour for all engineering disciplines and degrees be orange. No symbolic rationale was given. ${ }^{87}$ Orange was, however, the last remaining unclaimed primary or secondary colour in the Code and it is a hue that is similar to the gold yellow colour of Science. Orange is also a fiery colour that recalls the ancient use of machines to harness and control power and energy, so it was perhaps an appropriate symbolic choice for degrees in Engineering and Technology.

This colour choice was communicated to the Intercollegiate Bureau, which began to list orange as the colour for Engineering within a year or two.

\section{Oratory: silver grey}

Besides approving degree colours for degrees in the professional sciences, another tendency of the Intercollegiate Bureau during this period was to assign degree colours to degrees in interdisciplinary subjects.

Bachelor of Oratory degrees (along with related degrees in Elocution) were offered at many schools at the turn of the century, including Temple University, Emerson College of Oratory, Boston University, and others. The National School of Elocution and Oratory in Pennsylvania-evidently quite a famous institution at the time-offered a Master of Oratory degree to graduate students. A few institutions (perhaps not very academically reputable) offered a Doctor of Oratory degree for a stated fee. These degrees in Oratory or Elocution were broadly defined to include public speaking (including preaching), vocal training, dramatic performance, singing, and the study of literature. I would therefore assume that degrees in Oratory initially used the white of Arts and Letters, particularly since rhetoric was one of the trivium within the artes liberales.

'Knowing the fondness of America for elocution,',8 graduates of these oratory schools must have used their persuasive skills on the Intercollegiate Bureau, for Oratory ${ }^{89}$ was soon

85 Baker, 'The Spring Term', p. 542. See also 'Academic Costume', The Harvard Graduates' Magazine, 18.70 (Dec. 1909), p. 293.

86 Lockmiller, p. 186.

87 Society for the Promotion of Engineering Education, Proceedings of the Thirteenth Annual Meeting [28 and 29 June 1905], 13 (1906), p. 5.

88 A sarcastic comment in T. Baty, Academic Colours (Tokyo: Kenkyusha Press, 1934), p. 71.

89 By mid-century 'Elocution' was an archaic term and 'Oratory' was on its way down the 
added to the list of official degree colours during this period and assigned the colour 'silver gray'. Silver is a colour traditionally associated with the god Mercury, whose eloquence and persuasiveness made him the messenger of the gods. From this association the phrase silver tongued' has come to describe someone with superior communication skills and is without a doubt the symbolic reason the Bureau assigned this colour to degrees in Oratory. ${ }^{90}$

\section{Physical Education: sage green}

\section{Humanics: crimson}

Two very strange additions to the Bureau's degree colour list occur during this period: Physical Education and Humanics. These are not degrees that appear in any of the degree lists above. 'Humanics' is a turn-of-the-century word coined to indicate the study of human nature, and is an educational philosophy emphasizing the integration of an individual's spirit, mind, and body towards the social service of others. On 7 April 1905 the Commonwealth of Massachusetts granted the International Young Men's Christian Association Training School in Springfield, Massachusetts, permission to confer Bachelor and Master of Humanics degrees within a curriculum that included 'four areas of study, namely, Christian ethics, the study of man physically, the study of man intellectually, and the study of man in his social relations'.91 This course of study was primarily for graduates who intended to work in administrative positions within the YMCA. At the same time the degrees of Bachelor and Master of Physical Education were also approved by the Massachusetts Legislature for students studying the pedagogy of physical training and health..$^{92}$

The International Young Men's Christian Association Training School became the International Young Men's Christian Association College in 1912, ${ }^{93}$ and soon thereafter the Intercollegiate Bureau approved the addition of Physical Education and Humanics to the list of official degree colours.

same linguistic path. So the degree colour is listed as 'Speech (Oratory)' in Natalia M. Belting, The History of Caps and Gowns (New York: Collegiate Cap \& Gown, 1958), pp. 10-11, and since the 1960 printing of the Academic Costume Code, the discipline has been listed as 'Oratory (Speech)' in that document. See Mary Irwin, ed., American Universities and Colleges, 8th edn (Washington: American Council on Education, 1960), p. 1135.

90 The 'Oratory' degrees of the late nineteenth and early twentieth centuries are most closely related what we would now call 'Communication' degrees, so today some universities will use silver for degrees in Communication, the overarching discipline for both Speech and Journalism (added to the Academic Costume Code in 1960) - two disciplines that are not otherwise found in either the 1895 Intercollegiate Code or the initial 1935 Academic Costume Code.

91 For a history of the Humanics programme at the International YMCA Training School, see 'The Humanics Philosophy of Springfield College,' Seth Arsenian, ed., MS, 1969, at <http://www3 .springfield.edu/homepage/library.nsf/63eae91952b62ceb45256bf1001dd684/\$FILE/humanics Philosophy.pdf> (or, more simply, at < http://bit.ly/1XujkEO>), accessed 16 June 2016. See also 'The Springfield Training School', Association Men, 32.9 (June 1907), p. 409. Today Humanics can be found in over seventy American universities and colleges primarily as a course of study (a concentration within a major) or certificate programme for students interested in working for non-profit, philanthropic, and service organizations. In most cases Humanics is not a major, so the student would graduate with a degree in Social Work or some other field.

92 'Chapter 276', Acts and Resolves Passed by the General Court of Massachusetts in the Year 1905 (Boston: Wright \& Potter, 1905), p. 196.

93 In 1953 the institution officially renamed itself 'Springfield College' after having used this title informally since the mid-1930s. 
Physical Education was assigned sage green. I do not know why the Bureau did not subsume this degree under Pedagogy (as it should have, Physical Education being a type of Education), but if the Bureau intended sage green to be a greyish mint-green colour, this would have indicated that they saw this degree as a combination of the light blue of Pedagogy and the green of health-related fields already in the Code. But this does not seem to have been the case. The most common definition of 'sage green' is that of a yellow-green hue, and this has been the shade used by academic costume manufacturers since at least the 1930s. (See, for instance, the fabric samples from 1938 shown in Fig. 6.) Did the Bureau understand Physical Education to be a discipline studying the science (yellow) of health (green)? Because the archives of the Intercollegiate Bureau are closed to researchers, we cannot know this with certainty, but without a doubt the yellow green shade selected for Physical Education was intended to count this degree colour as one of the 'allied health sciences' as we would say today.

Humanics was assigned crimson, and here the colour choice seems more straightforward. The Bureau must have decided that a shade of red would be appropriate for a degree that wasn't a Divinity degree (scarlet) but was of a related spiritual or religious flavour. ${ }^{94}$

On 1 February 1926 the Commonwealth of Massachusetts granted the International Young Men's Christian Association College permission to confer the traditional Bachelor of Science and Master of Education degrees, and by the 1930s the Master of Humanics degree had disappeared (the BH, BPE, and MPE degrees remained alongside the BS and MEd degrees). ${ }^{95}$ As a result, the Intercollegiate Bureau's listing of 'Humanics' became something of an anachronistic lame duck, and although it was grandfathered into the American Council on Education's Academic Costume Code of 1935 (see below) it was replaced by 'Humanities' (also crimson) a mere five years later. ${ }^{96}$ However, the Intercollegiate Bureau continued to recognize Humanics in their official list of degree colours until at least the late 1940 s. ${ }^{97}$

\section{Economics: copper}

A final odd choice by the Bureau for official degree colour sanction was Economics. Like Oratory, Physical Education, Humanics, and Public Health (see below), Economics is an

94 The colour is listed as 'dark crimson' in degree colour lists from academic costume manufacturers besides Cotrell \& Leonard, probably to clearly distinguish the shade from the scarlet of Divinity. See 'Academic Caps and Gowns', Costume Through the Ages (Philadelphia: Waas \& Son, 1928), p. 29; Helen Walters, The Story of Caps and Gowns (Chicago: E. R. Moore, 1939), pp. 14, 18; and Emanuel I. Cohen, History of Academic Caps, Gowns and Hoods (Philadelphia: National Academic Cap \& Gown, 1940), p. 37. The Intercollegiate Bureau and the American Council on Education (1935 edn only) continued to list the colour as 'crimson'.

95 'Chapter 11', Acts and Resolves Passed by the General Court of Massachusetts in the Year 1926 (Boston: Secretary of the Commonwealth, 1926), p. 7. See also International Young Men's Christian Association College Catalog 1927-1929 (Springfield: n.p., c.1929), pp. 17-18; International Young Men's Christian Association College Catalog 1931-1933 (Springfield: n.p., c.1933), p. 82.

96 Clarence Stephen Marsh, ed., American Universities and Colleges, 4th edn (Washington: American Council on Education, 1940), p. 1057. This change makes little sense, as the Humanities are generally considered to be part of the Liberal Arts, which were already approved to use the degree colour of white. Humanities remained in the Academic Costume Code until the 1960 edition, when crimson was illogically given to Journalism (as Journalism is a communications subject and Oratory was already assigned a degree colour).

97 Hoppner, p. 14. 


\section{FIG. 6}

These fourteen rayon swatches were used to design banners for each of the Colleges and Schools within the University of Minnesota in the late 1930s. The colours were obviously chosen with the Intercollegiate Bureau degree colours in mind, and additionally include the "old gold' institutional colour of the University (lower left).

The labels for Agriculture and Library Science appear to be switched (the 'maize' of Agriculture should be lighter than the 'Iemon' of Library Science), and the shade of what is here called 'drab' is unlike any I have ever seen on the edging of a Business hood. This is because the University interpreted drab to mean a colour similar to what they described as 'old pewter'. Although the swatch is unlabelled here, the University redefined crimson as signifying 'Humanities', not 'Humanics', but did not explain why the Humanities weren't already included in the white of 'Liberal Arts'. The unlabelled

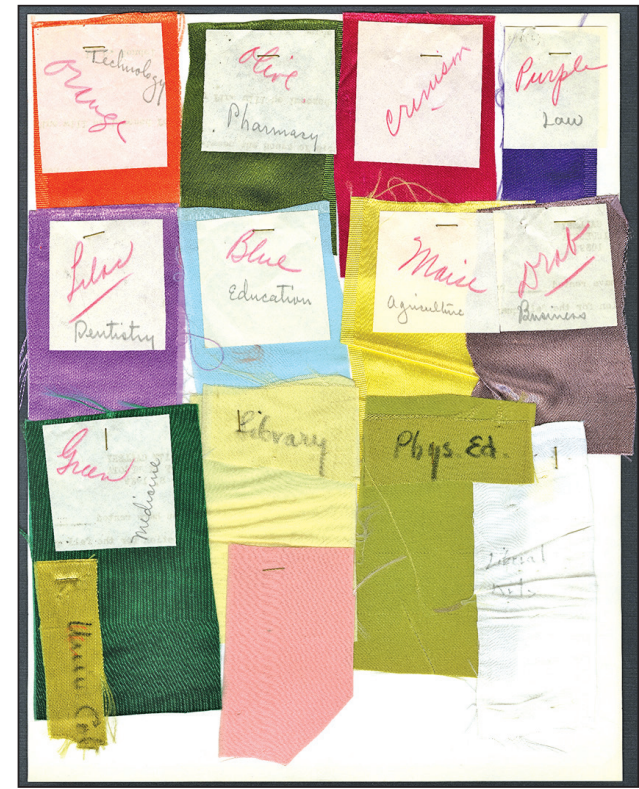

swatch at the bottom was intended to be salmon in colour (for Public Health), not pink (for Music). Photograph courtesy of University Archives, University of Minnesota.

interdisciplinary or cross-disciplinary subject. It was not, however, a common degree title in the early decades of the twentieth century, which makes the Bureau's decision to assign a degree colour to this (non-degree) subject very strange.

I have not found any school that offered a Bachelor, Master, or Doctor of Economics during this period, although the Wharton School of Finance and Commerce offered a 'Bachelor of Science in Economics' degree beginning in 1912 when it was 'separated from the College Department [what other universities would call the College of Arts and Sciences], having been organized with their own faculty and dean'. ${ }^{98}$ If this is the reason the Intercollegiate Bureau created a degree colour for Economics, it indicates that the Bureau did not only look at the degree title when assigning degree colours, but took into consideration the way the institution organized its academic units. But if this is true, why was Economics granted a colour when a colour for 'Commerce and Accountancy' already existed that could have been used for all degrees granted by this School of Finance and Commerce?

On the other hand, if the Bureau created a special degree colour because the new School of Finance and Commerce offered a 'Bachelor of Science in Economics', why were tagged BS degrees at other institutions not also granted colours? Tagged degrees were be-

98 General Alumni Catalogue of the University of Pennsylvania: 1922 (Philadelphia: General Alumni Society, 1922), pp. 7, 298. 
coming more common in the Sciences-'Bachelor of Science in Agriculture', 'Bachelor of Science in Chemistry', 'Master of Science in Electrical Engineering', 'Master of Science in Biology' are a few examples from the 1910s and 1920 s $^{99}$ - but as I have pointed out above, by the 1930s the Bureau was clear in stipulating that 'a degree conferred as "Bachelor of Science in Engineering" requires the golden yellow of Science and not the orange of Engineering. ${ }^{100}$ Perhaps this policy had not yet been formulated in the 1910s when the Bureau assigned a colour to Economics, but was later adopted in light of the increasing number of tagged degrees.

For whatever reason, around the time the Wharton School of Finance and Commerce was created in 1912 the Intercollegiate Bureau assigned 'copper' to Economics, which is a colour describing a metal that has been used for coinage throughout the world. It is also a colour similar to the dark shade of 'drab' that Cotrell \& Leonard used for related degrees in Commerce and Accountancy. But unfortunately, it is a reddish-brown colour that is easily confused with the russet of Forestry-another reason to question the Bureau's decision to add the copper of Economics to the official degree colour list.

Without documents from the archives of the Intercollegiate Bureau of Academic Costume for confirmation, it is not possible to identify the specific dates these six degree colours were officially adopted. But extant Cotrell \& Leonard catalogues from this period show that Engineering and Oratory began to be included in the Bureau's list of official degree colours at some point between 1906 and 1909. ${ }^{101}$ The Bureau added Agriculture to the list of official degree colours between 1909 and 1915, with Physical Education, Humanics, and Economics likely added between 1912 and 1915. ${ }^{102}$

\section{Dormancy and eclipse (1915-35): American Council on Education steps in}

By 1915 over 600 colleges and universities were using the Intercollegiate Code of Academic Costume, ${ }^{103}$ and the Intercollegiate Bureau of Academic Costume was finishing a busy twenty-year period in which the number of official degree colours had nearly tripled. A new degree colour added to the official list between 1915 and 1918-'salmon' for degrees in Public Health-brought the total number of official degree colours approved by the Bureau to twenty-two by the end of the Great War (Fig. 7). Strangely, however, the Bureau would not approve any new degree colours until the late 1930s.

\section{Public Health: salmon}

'Public Hygiene' and 'Public Health' were early examples of interdisciplinary programmes in American academia, each reflecting a different strategy to health reform. Inspired by

99 See, for instance, Frank W. Haycraft, The Degrees and Hoods of the World's Universities and Colleges (Ware: Jennings \& Bewley, 1923), p. 51.

100 The History of Academic Costume in America, p. 11.

101 See Society for the Promotion of Engineering Education, Proceedings of the Thirteenth Annual Meeting [28 and 29 June 1905], 13 (1906), p. 5. On p. 14 of Concerning Caps, Gowns and Hoods Bulletin, 20 (c. 1905), it is stated that 'Holders of Engineering degrees in Faculties are rated as Masters of Science' (see Fig. 5). But on p. 14 of Concerning Caps, Gowns and Hoods, Bulletin 21 (c. 1906), the text omits the reference to Science and simply says that 'Holders of Engineering degrees in Faculties are rated as Masters'. By the time Bulletin 24 (c. 1909) was published, Engineering had been added to the degree colour list on p. 13 as using orange.

102 'Academic Dress', The World Almanac and Encyclopedia 1916 (New York: Press Publishing, 1915), p. 598.

103 'Academic Dress', p. 598. 
German institutes of hygiene, Public Hygiene advocates stressed a research approach with strong ties to medical schools. Public Health educators, on the other hand, tended to imitate British health officer training programmes and emphasize administrative and practical training with strong ties to academic programmes in sanitary engineering separate from medical schools. ${ }^{104}$

This distinction between the way the two terms were used was not always so clearcut, but in the first decades of the twentieth century there was indeed fierce competition between sanitary engineers and medical professionals over the control of public health resources and approaches. This competition is reflected in the degree title and degree colour the Intercollegiate Bureau selected for the academic study of sanitation, bacteriology, disease prevention, epidemiology, health education, and social reform.

In 1909 the University of Pennsylvania began the first 'Doctor of Public Hygiene' degree programme in the US, conferring the first DrPH degree in $1911 .{ }^{105}$ Reflecting the tendency of Public Hygiene programmes to be affiliated with medical schools, at Pennsylvania the 'Laboratory of Hygiene' was under the dean of the medical school and staffed by faculty with MD degrees, and Doctors of Public Hygiene and Doctors of Medicine both used the degree colour of green. ${ }^{106}$ At the same time, Harvard University conferred the first 'Doctor of Public Health' degree in $1911,{ }^{107}$ but this was a post-doctoral degree conferred on physicians already holding an MD degree, 'or to other properly qualified persons' who had completed a minimum of one year on a research project approved by the Faculty of Medicine. ${ }^{108}$

Along with Pennsylvania and Harvard, Columbia University and Yale University had either recently started or wanted to start programmes in disease prevention and health education when a 1914 public health conference was held in the offices of the General Education Board of the Rockefeller Foundation in New York. Representatives of Pennsylvania, Columbia, the University of Chicago, Harvard, Johns Hopkins University, and a number of important New York City and New York State health administrators attended the conference. The commissioners recommended the formation of a national school of public health that would be affiliated with a university but be separate from a medical school, clearly favouring the 'Public Health' approach over the 'Public Hygiene' approach. Both Harvard and Columbia jockeyed for this honour. But when the Welch-Rose Report from the commission was published in 1915, sharp controversy arose over the report's emphasis on a medical (or 'hygiene') approach to the training of public health experts, which was not the approach favoured by the representatives from New York.

104 For an excellent summary of the early history of Public Hygiene and Public Health programmes in the United States see Elizabeth Fee, 'The Welch-Rose Report: Blueprint for Public Health Education in America' at <http:/www.deltaomega.org/documents/WelchRose.pdf>, accessed 17 June 2016.

105 University of Pennsylvania School of Medicine: Announcement for the 154th Annual Session (Philadelphia: University of Pennsylvania, April 1919), p. 15. See also 'Undergraduate and Professional Degrees Conferred by the University of Pennsylvania (1757-2003): School of Hygiene and Public Health', at <http://www.archives.upenn.edu/histy/features/degrees/pubhyg.html>, accessed 6 June 2016.

106 Catalogue of the University of Pennsylvania: 1916-1917 (Philadelphia: University of Pennsylvania, 1917), pp. 25, 519 .

107 Harvard School of Public Health: 1989-1990 Register (Boston: Harvard University, 1990), p. 3. I have been unable to discover the degree colour or colours used by Harvard graduates in Public Health from 1911 until 1920 or so.

108 Harvard University Catalogue: 1911-12 (Cambridge, Mass.: Harvard University, 1911), p. 731.

66 
The commission ultimately chose Johns Hopkins, in Maryland, because of its strong medical school, and in 1916 the Rockefeller Foundation granted a quarter of a million dollars to Johns Hopkins to form a 'School of Hygiene and Public Health'-an unsubtle semantic attempt to mollify supporters of the social/scientific approach to public health. The selection of Johns Hopkins and its Public Hygiene approach left representatives from Harvard and Columbia bitter.

This may explain why the Intercollegiate Bureau-always one to favour north-eastern schools-chose to title the degree subject as 'Public Health' instead of 'Public Hygiene' and why it did not select a shade of green for the degree colour, as it had for other allied health disciplines that had received degree colours. But why salmon? Salmon is a reddish pink with a strong yellow tone, and this choice of shade may reflect the Bureau's opinion that Public Health was a scientific subject, not a medical one.

The Bureau's choices were a hollow victory by advocates of the Public Health model. For although the University of Pennsylvania (and other institutions) followed the Bureau's stipulations and had reassigned their Doctor of Public Hygiene degree colour from green to salmon by $1918,{ }^{109}$ the pedagogical approach of this discipline at most universities remained strongly in the medical school tradition.

In striking contrast to the flurry of degree colour approvals during the twenty years before the Great War, after the conflict was over the Intercollegiate Bureau of Academic Costume entered into a moribund period of stasis that lasted another twenty years, during which not a single degree colour was added.

This inactivity was probably caused by a lack of visionary leadership. Gardner Cotrell Leonard unexpectedly died at the age of fifty-five on 15 April 1921 when he fell from the roof of the Cotrell \& Leonard firm in Albany. Leonard had gone to the roof of the store to inspect a leak, stumbled, lost his balance, and fell over the edge of the roof five storeys onto the concrete foundation of a hotel that had been demolished next door. He sustained multiple injuries, including a fractured skull, and instantly died, leaving behind a wife and two teenaged children. ${ }^{10}$ With Leonard's passing, the Intercollegiate Bureau lost the charismatic and energetic director who had guided it for over thirty years.

The dormancy of the Intercollegiate Bureau of Academic Costume during this period, no doubt exacerbated at the end of the decade by the onset of the Depression and its chilling effect on the Cotrell \& Leonard firm, is probably what led the American Council on Education, an association of college and university presidents established in 1918, to form a 'Committee on Academic Costume' in 1932

to determine whether revision and completion of the academic code adopted by the conference of the colleges and universities in 1895 is desirable at this time and, if so, to draft a revised code and present a plan for submitting the code to the consideration of the constituent members of the Council. ${ }^{11}$

109 Catalogue of the University of Pennsylvania: 1918-1919 (Philadelphia: University of Pennsylvania, 1919), p. 37.

110 Botsford, E. Herbert, Williams College Bulletin: Alumni Obituary Record 7:3 (1921-1922) (Williamstown: Williams College, April 1922), p. 162. Also 'Albany County', American Education, 24.9 (May 1921), p. 416. Also 'Obituary: Gardner C. Leonard', The American Hatter, 50.10 (May 1921), p. 84.

111 'An Academic Costume Code: Report of Committee on Academic Costume', in The Educational Record (July 1935; reprint Washington: American Council on Education, 1935), p. 4. 
On 30 April 1935 the commission submitted an 'Academic Costume Code' that was endorsed by the American Council on Education and remains in force today, differing from the 1895 Intercollegiate Code 'in only a few, and those very minor, details'. ${ }^{112}$

For example, the 1935 Academic Costume Code ${ }^{113}$ approved the entire set of twenty-two degree colours adopted by the Intercollegiate Bureau of Academic Costume with only miniscule changes: 'Fine Arts' was changed to 'Fine Arts, including Architecture' to state how the Bureau was already defining what constituted a fine arts subject; 'Laws' and 'Theology and Divinity' reverted to the original 'Law' and 'Theology' of the 1895 Code; the colour for Philosophy was clarified as being 'dark blue' rather than 'blue' (describing the actual colour used on gowns by Cotrell \& Leonard and other firms); and the 'gold yellow' of Science was renamed 'golden yellow'.

The 1935 Code also retained the prescription that these are degree colours, 'distinctive of the subject named in the diploma given in conferment of the degree'.

Left unclear in the new Code was whether the American Council on Education had the right to approve new degree colours. However, the introductory preface to the 1935 Code stated that the Intercollegiate Bureau of Academic Costume is

a source of information and guidance in such matters. Of this organization the firm of Cotrell and Leonard of Albany, New York, was designated by the Regents [of the University of the State of New York] to act as 'repository'. In that capacity this firm has continued and still continues to serve.

In retrospect these words by the American Council on Education seem disingenuous. The ACE was saying that the Intercollegiate Bureau was an important source of information about degree colours and other matters related to academic dress in the United States. The ACE was also saying that the 1895 Code needed very little revision. But it is equally clear that the ACE was granting itself the authority to rewrite the 1895 Code and thus saw itself as the more important of the two codifying organizations. In other words, the American Council on Education was saying: 'thanks for your hard work, Intercollegiate Bureau, but we'll take over from here'.

The impact of this transfer of authority will be the subject of another article. But during the forty years the Intercollegiate Bureau of Academic Costume promoted the Intercollegiate Code and supervised the adoption of degree colours used by colleges and universities, a very successful means of communicating a graduate's degree and discipline in a standardized and colourful system was created. But like a spider's web that shimmers in the morning sun, the effect was beautifully iridescent but fragile. The Bureau's degree colour system was successful in attracting adherents, but this adherence was voluntary, and no one enforced obedience to the Code or the degree colours approved by the Bureau. To be sure, there were knots in the web-some of the approved degrees and/or their colours seem positively bizarre or confusing-but overall the Bureau was doing good work, and most colleges and universities realized that a standardized list of degree colours was both a useful semiotic tool and a handsome sartorial flourish. Others, however, began to feel trapped

112 Ibid. Despite the commission's description of the changes as few and minor, a look into its records reveals that they have been many and, often, significant. See Wolgast, 'The Intercollegiate Code', pp. 22-34. - Ed.

113 Other sources refer to this as the ' 1932 Code'. I prefer to identify this Code by the date of adoption (1935) rather than the date the ACE Committee on Academic Costume was formed (1932). 


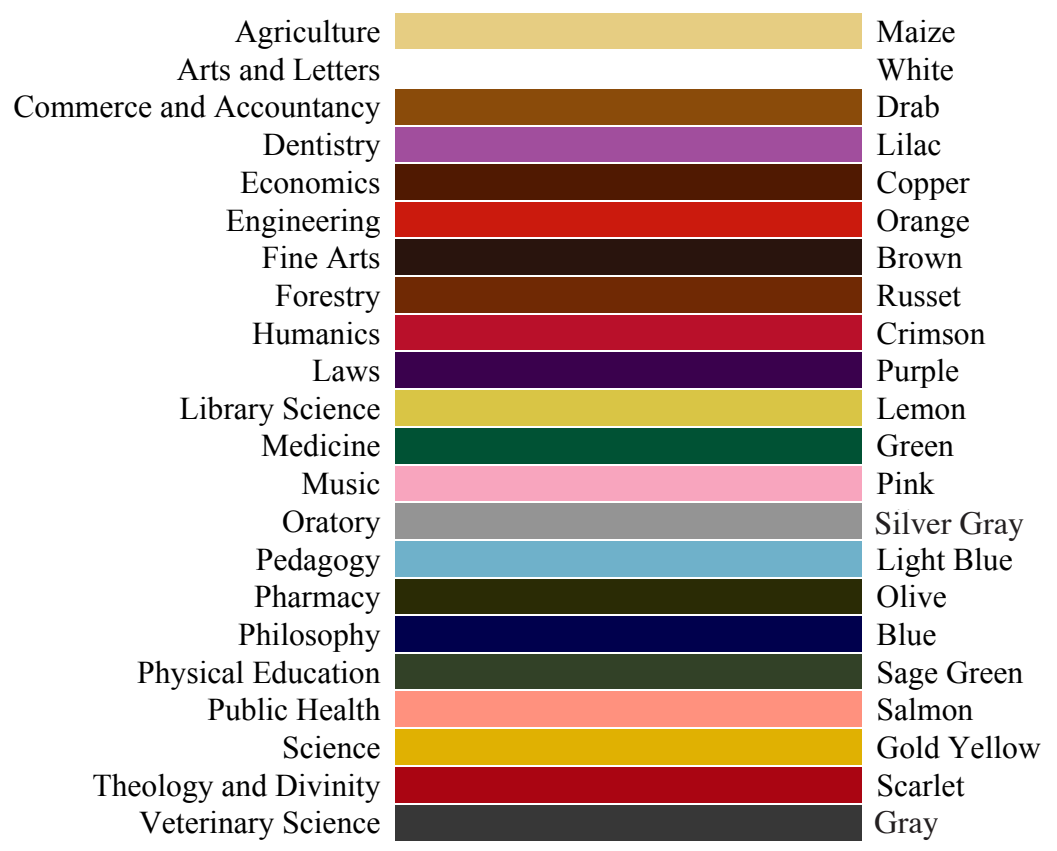

FIG. 7

The twenty-two degree colours approved by the Intercollegiate Bureau between 1895 and 1918, a list that did not change until 1936 at the earliest. The colour values on this chart are approximate; however, they are based on velvet fabric samples from late 1930s or early 1940s supplied by the Cotrell \& Leonard firm, who tended to use darker shades of the colours than one might expect given the description of the colour. This was probably to avoid too great a contrast between the black gown and the degree colour trim. One will immediately notice that it is difficult to distinguish some of the degree colours from others-a problem the American system of faculty colours has never resolved.

by this web, and there would be defections from and rebellions against the Bureau's degree colour system in coming years.

More problematic, however, was the fact that American academia was changing, new degrees were being created, old degrees were dying out, and just as the gusts of wind from a storm can buffet and shred a gossamer web to tatters, pedagogical changes in the 1930s, 1940 s, and the post-war period would have a destructive effect on the Intercollegiate Bureau's simple latticework from the Gilded Age. But that is a story for a later article. 

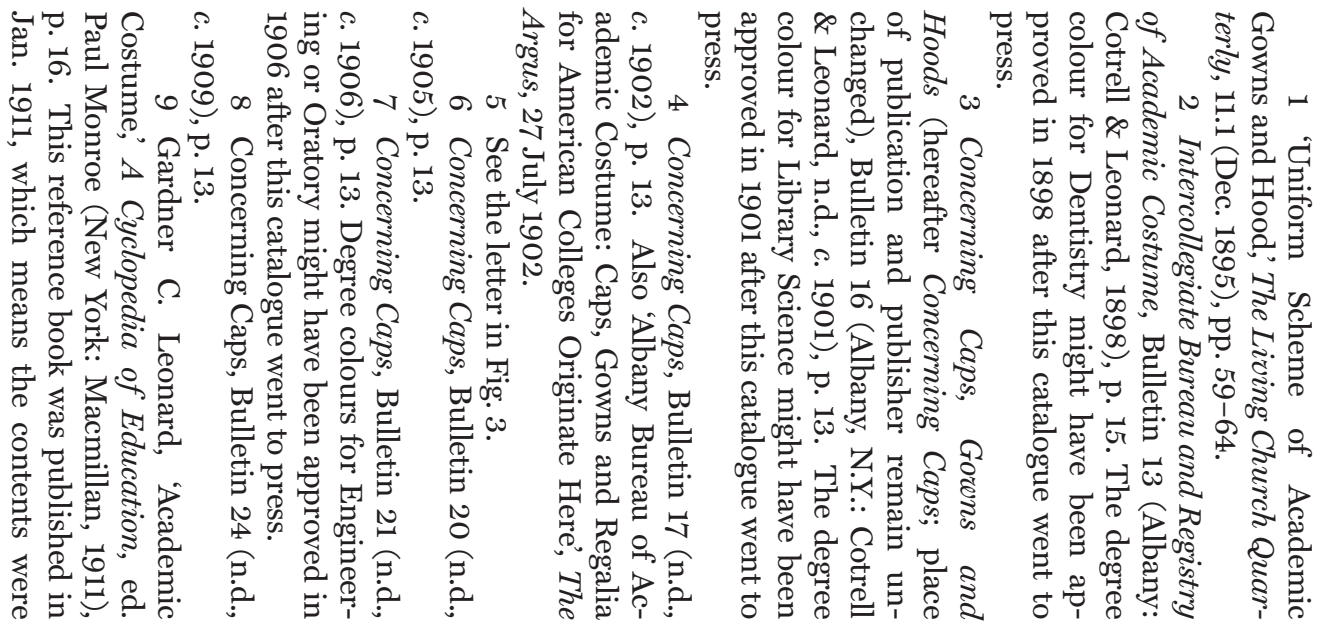

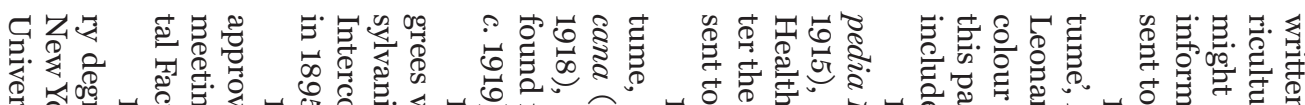

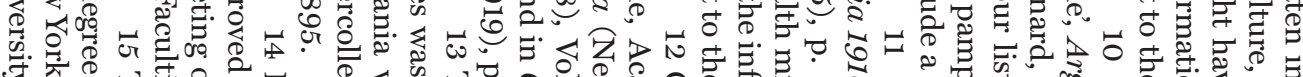

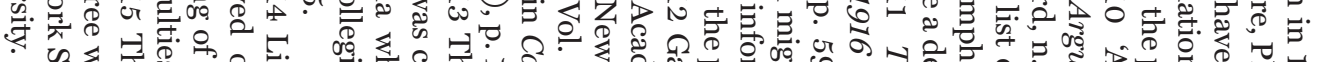

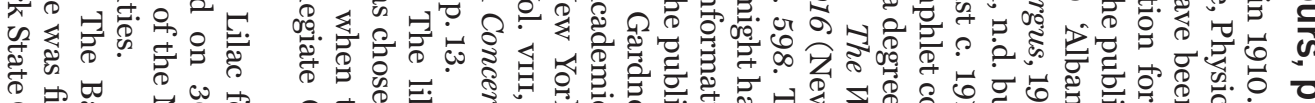

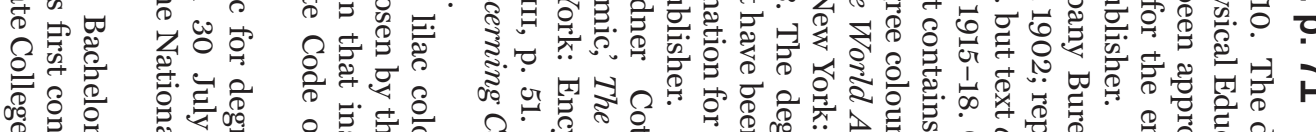

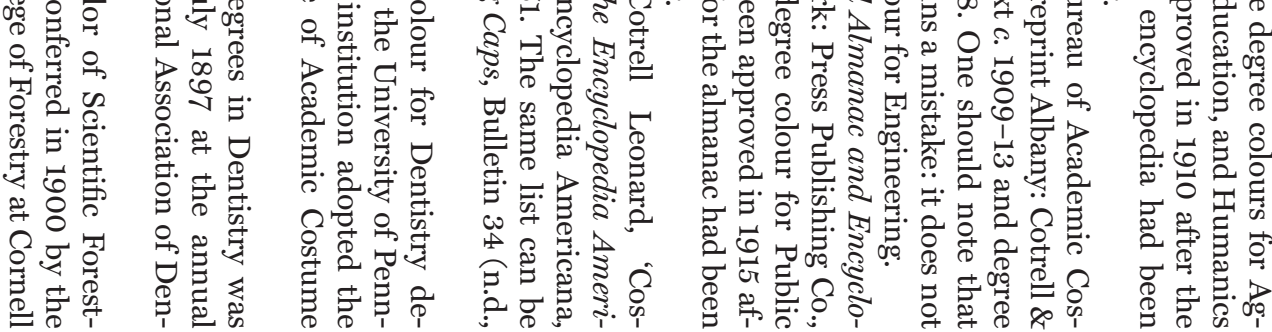

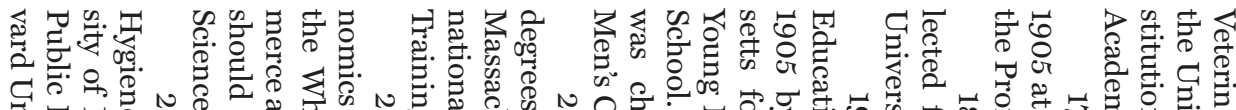

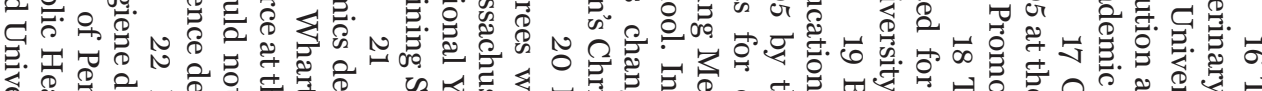

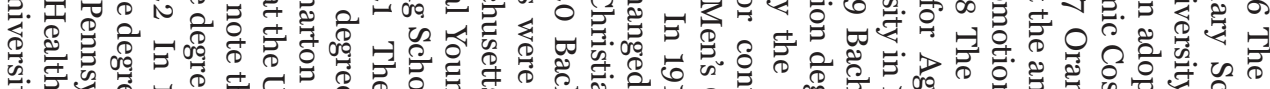

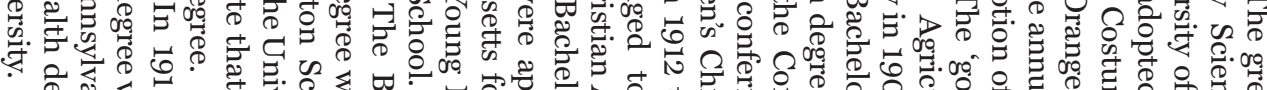

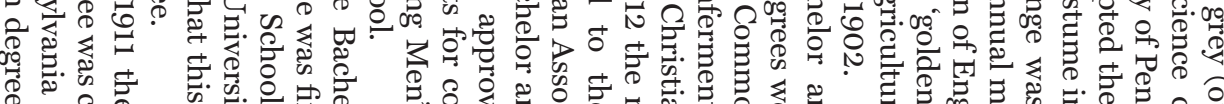

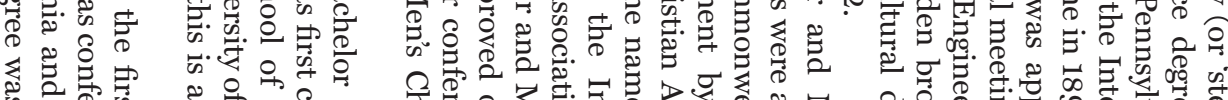

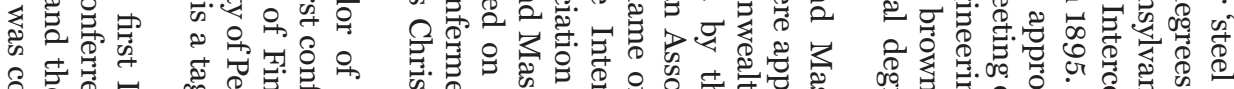

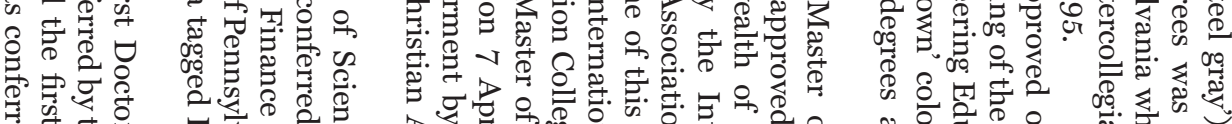

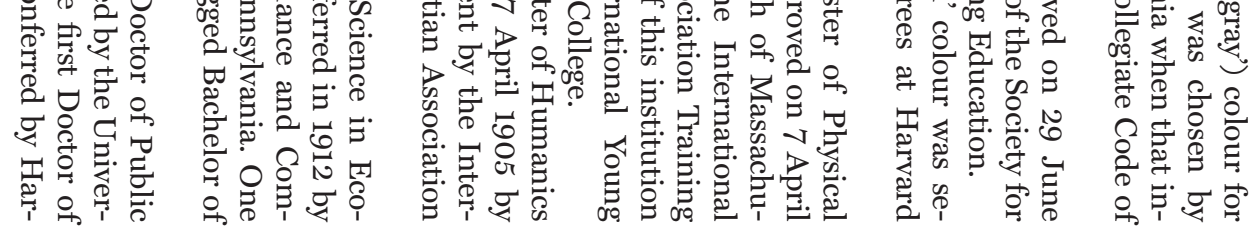




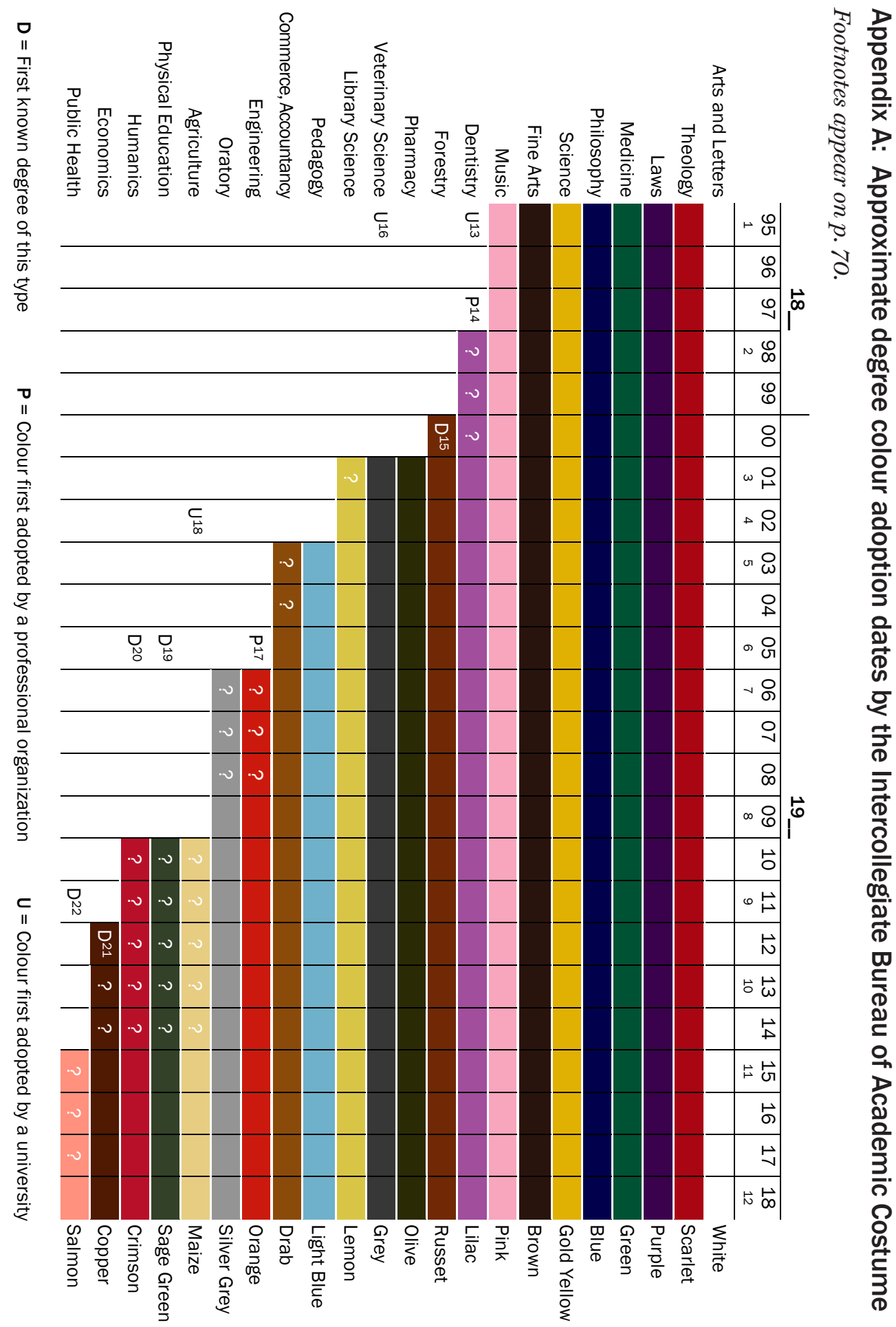




\title{
Appendix B: The Intercollegiate Code (or System) Of Academic Costume ${ }^{114}$ (Adopted 16 May 1895)
}

\author{
ACADEMIC COSTUME
}

SECTION 1: The following described academic costume is adopted, to be worn upon all appropriate occasions, as indicating the several Degrees and the Faculties to which they pertain. ${ }^{115}$

\section{GOWNS:}

1. Pattern-Those commonly worn, with pointed sleeves for the Bachelor's Degree, with long closed sleeves for the Master's Degree, and with round open sleeves for the Doctor's Degree. ${ }^{116}$

2. Material-Worsted stuff for the Bachelor's Degree, silk for the Master's and Doctor's Degrees.

3. Color-Black.

4. Trimmings-For the Bachelor's and Master's Degrees the gowns are to be untrimmed. For the Doctor's Degree the gown is to be faced down the front with black velvet, with bars of the same across the sleeves; or the facings and crossbars may be of velvet of the same color as the binding or edging of the hood, being distinctive of the Faculty to which the Degree pertains.

HOODS:

1. Pattern-The pattern usually followed by Colleges and Universities, save as modified below.

2. Material-The same as that of the gown.

114 This title is taken from contemporary descriptions of the Code, but is not in any of the original documents cited below, which often begin with 'Academic Costume'. I have retained the original spelling, capitalization, and grammar of these documents but have modernized the punctuation and formatting style for the document reproduced here. The earliest copies of the Code I have found are in the Minutes of the Trustees of Columbia, Vol. xv, 3 June 1895, pp. 174-75, University Archives, Columbia University; Princeton College Bulletin, 7.4 (November 1895), pp. 91-92; University Bulletin [of Columbia University], 12 (December 1895), pp. 8-9; 'Uniform Scheme of Academic Gowns and Hood', The Living Church Quarterly, 11.1 (Dec. 1895), pp. 59-64; University Record [of the University of Chicago], 1.11 (12 June 1896), p. 198; New York University: University Graduate School Announcements for 1896-1897 (New York: New York University, 1896), pp. 16-17; University Bulletin [of the University of Pennsylvania], 3.8 (May 1899), p. 303.

115 Yale University revised this awkwardly worded opening sentence to read: 'The following academic costume is permitted to be worn upon all appropriate occasions, as indicating the several Degrees and the Faculties to which they pertain.' Princeton made a similar change to the version in their catalogue.

116 The University of Pennsylvania, which was not one of the members of the Intercollegiate Committee that drafted the Code, added a footnote to this part of the Code when it adopted it in 1895: 'In all cases when the Doctor's degree is mentioned, reference is made onLY to degrees in Philosophy, Divinity, Letters, Music, Science, or Laws. Holders of the degrees of Doctor of Medicine, Doctor of Dental Surgery, Doctor of Veterinary Medicine, will wear gowns and hoods similar in all respects to those prescribed for Bachelors' [original italics and capitalization]. See University Bulletin [of the University of Pennsylvania], 3.8 (May 1899), p. 303. 
3. Color-Black.

4. Length-The length and form of the hood will indicate the Degree, as follows: For the Bachelor's Degree, the length shall be three-fourths that of the Master's Degree. The Master's Degree shall be of the customary length, not exceeding four feet; and the Doctor's Degree shall be of the same length but have panels at the sides. ${ }^{117}$

5. Linings-The hoods shall be lined with the official color ${ }^{118}$ of the University (or College). ${ }^{119}$

6. Trimmings-The binding or edging, not more than six inches in width, ${ }^{120}$ to be of silk, satin or velvet, the color to be distinctive of the Faculty to which the Degree pertains, thus:

Faculty of Arts and Letters, white.

Faculty of Theology, scarlet.

Faculty of Law, purple.

Faculty of Medicine, green.

Faculty of Philosophy, dark blue.

Faculty of Science, gold yellow.

Faculty of Fine Arts, brown.

Faculty of Music, pink.

CAPS:

The caps shall be of the material and form generally used, and commonly called mortarboard caps. The color shall be black. The Doctor's cap may be of velvet. Each cap shall be ornamented with a long tassel attached to the middle point at the top. The tassel of the Doctor's cap may be, in whole or in part, of gold thread.

SECTION 2: Members of the Governing Body shall be entitled, during their term of office, to wear the gown of the highest dignity - that of the Doctor's Degree-together with the hood appropriate to the Degree which they may have severally received. Members of the Faculties, and any person officially connected with the University (or College) who have been recipients of academic honors from other universities of colleges in good standing, may assume the academic costume corresponding to their Degree, as described in the foregoing section, provided, that such right shall terminate if such persons shall cease to be connected with the University (or College). The President and Deans of Faculty may adopt distinctive badges, not inconsistent with the costume hereinbefore described.

117 The University of Pennsylvania clarified this section when they adopted the Code in 1895, stipulating that the bachelor's hood be 3 feet in length, the master's hood be 4 feet in length, and the doctor's hood be 4 feet in length with panels at the sides. Ibid.

118 The original text seems to have used the singular form of this noun. When colleges and universities adopted the Code and incorporated it into their bylaws they typically substituted the word 'colors' followed by a description of the institution's two school colours.

119 The University of Pennsylvania clarified this section when they adopted the Code in 1895, stipulating that the school colours of their institution (red and blue) be arranged in the form of a chevron. Ibid.

120 The University of Pennsylvania clarified this section when they adopted the Code in 1895 , stipulating that the edging of all hoods would be 4 inches in width. Ibid. 


\section{Select bibliography of additional archival material in the US (1895-1935)}

These books, journal articles, pamphlets, and catalogues are arranged by date of publication and are additional sources of general information about American academic dress. For information about a more specific topic within this subject please consult the footnotes in this essay.

\section{Books and journal articles}

'Editor's Study', Harper's New Monthly Magazine, 94:561 (February 1897), pp. 481-83.

'The Inter-Collegiate Cap and Gown System', The Miami Student, 23:5 (February 1904), pp. 156-57.

Chittenden, Alice Hill, 'The Academic Cap, Gown and Hood: Their Origin and Significance', The Chautauquan, 43:6 (March-April 1906), pp. 562-67.

Barker, Edwin L., 'Academic Millinery', The American Educational Review, 30:12 (September 1909), pp. 602-04.

'Universities', in The Encyclopaedia Britannica, Vol. xxvir (New York: The Encyclopaedia Britannica Co., 1911), pp. 777-80.

'Academic Costume', The American Educational Revierw, 34:8 (May 1913), pp. 414-15.

'Marks Distinguishing Degrees', The Anchora of the Delta Gamma Fraternity (1 November 1914), p. 93.

'Academic Dress', in The World Almanac and Encyclopedia 1914 (New York: Press Publishing, 1913), p. 610 , and 1914, p. $639 ; 1915$, p. $598 ; 1916$, p. $714 ; 1917$, p. 630.

'The Intercollegiate Code: Its Inception and Significance', The Trident of Delta Delta Delta, 26:3 (April 1917), pp. 355-56.

Ward, Harry Parker, The American College Catalog (Columbus: The Champlin Press, 1917).

Jewett, Almira, 'Color Symbolism', The Quarterly Journal of the University of North Dakota, 9:1 (October 1918), pp. 50-71.

Leonard, Gardner Cotrell, 'Costume, Academic', in The Encyclopedia Americana, Vol. viII (New York: The Encyclopedia Americana Corporation, 1918), pp. 48-52.

\section{Academic dress catalogues}

Intercollegiate Bureau and Registry of Academic Costume Bulletin 13 (Albany: Cotrell \& Leonard, 1898). Also, Concerning Caps, Gowns and Hoods, the title under which the series continued, Bulletins 17, c. 1902; 20, c. 1905; 21, c. 1906; 24, c. 1909; and 34, c. 1919.

'Academic Caps and Gowns', in Costume through the Ages (Philadelphia: Waas \& Son, 1928).

If the reader has a copy of any pre-1935 American academic clothing catalogue that is not listed above, particularly Bulletins of Concerning Caps, Gowns and Hoods missing from the bibliography of this essay, the author would welcome correspondence about those catalogues as well as photographic scans of their contents if possible. The author is also seeking copies of the 2nd and 4th printings of The Story of Caps and Gowns by Helen Walters. I may be reached through the editor of the Transactions of the Burgon Society. 